University of Louisville

ThinkIR: The University of Louisville's Institutional Repository

Electronic Theses and Dissertations

$5-2007$

\title{
Making birth control acceptable : the development of the twentieth century birth control movement.
}

Elizabeth Caskey 1983-

University of Louisville

Follow this and additional works at: https://ir.library.louisville.edu/etd

\section{Recommended Citation}

Caskey, Elizabeth 1983-, "Making birth control acceptable : the development of the twentieth century birth control movement." (2007). Electronic Theses and Dissertations. Paper 221.

https://doi.org/10.18297/etd/221

This Master's Thesis is brought to you for free and open access by ThinkIR: The University of Louisville's Institutional Repository. It has been accepted for inclusion in Electronic Theses and Dissertations by an authorized administrator of ThinkIR: The University of Louisville's Institutional Repository. This title appears here courtesy of the author, who has retained all other copyrights. For more information, please contact thinkir@louisville.edu. 


\author{
By \\ Elizabeth Caskey \\ B.A., Bellarmine University, 2005
}

\begin{abstract}
A Thesis
Submitted to the Faculty of the

Graduate School of the University of Louisville

in Partial Fulfillment of the Requirements

for the Degree of
\end{abstract}

Master of Arts

Department of History

University of Louisville

Louisville, Kentucky

May 2007 
MAKING BIRTH CONTROL ACCEPTABLE: THE DEVELOPMENT OF THE TWENTIETH CENTURY BIRTH CONTROL MOVEMENT

By

Elizabeth Caskey

B.A., Bellarmine University, 2005

A Thesis Approved on

April 5, 2007

by the following Thesis Committee:

Thesis Director 


\section{ACKNOWLEDGEMENTS}

I would like to think my sister for helping me with research even though she did not want to. I would also like to thank Dr. Thomas Mackey, my thesis advisor, for his support and patience. Dr. Tracy K'Meyer and Dr. Jasmine Farrier have my thanks for agreeing to be on my committee. Finally, all of my friends who have tolerated me throughout the entire thesis process have my gratitude. 


\title{
ABSTRACT \\ MAKING BIRTH CONTROL ACCEPTABLE: THE DEVELOPMENT OF THE TWENTIETH CENTURY BIRTH CONTROL MOVEMENT
}

\author{
Elizabeth Caskey
}

$$
\text { May 12, } 2007
$$

This thesis is an examination of the tactics used by individuals in the development of the twentieth century birth control movement. It focuses on the creation of a national organization that directed the movement throughout the United States. The twentieth century political and economic environment influenced the birth control movement, but key individuals navigated the environment and developed a program of dissemination and education that furthered the cause of birth control. The intention is to show that Sanger and her cohort expanded upon nineteenth century efforts to provide people reproductive control. The twentieth century political and economic environment influenced the birth control movement, but key individuals navigated the environment and developed a program of dissemination and education that furthered the cause of birth control. The thesis has four chapters including an introduction and conclusion. 


\section{TABLE OF CONTENTS}

Acknowledgements

Abstract

Introduction: Contraception in the Nineteenth Century................................... 1

Anthony Comstock and the Criminalization of Contraception ............. 4

Challenging the Laws ....................................... 8

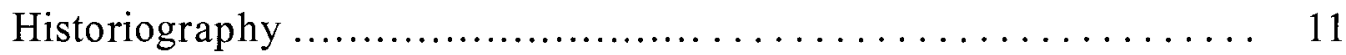

Chapter 2: Organizing for Birth Control $\ldots \ldots \ldots \ldots \ldots \ldots \ldots \ldots \ldots, 22$

Margaret Sanger's Early Career ........................................................... 23

Mary Ware Dennett ......................................................... 28

Sanger's Return: A New Direction ........................................... $\quad 35$

The American Birth Control League .................................. 42

Chapter 3: Kentucky Birth Control League .................................... 46

Chapter 4: Conclusion ........................................................ 64

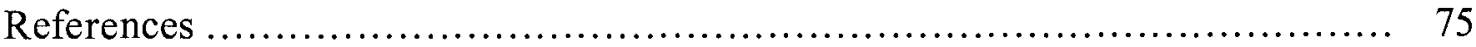

Curriculum Vitae .......................................................... 84 


\title{
INTRODUCTION: CONTRACEPTION IN THE NINETEENTH CENTURY
}

\begin{abstract}
Any movement seeking to produce change, without recourse to force, must mobilize public support if it is to succeed. This requires education. People must come to recognize as important the values upon which the movement stands. ${ }^{1}$
\end{abstract}

In 1830, when Robert Dale Owen published Moral Physiology; or, A Brief and Plain Treatise on the Population Question he was the first person to advise Americans on a method of contraception, but he was not the last. Owen initiated a movement to make information that allowed married couples to control their conception public. The knowledge Owen and his successors introduced had existed for centuries, but for the first time it appeared in a publicly accessible medium. These mid-nineteenth century radicals, however, were not an organized movement, but individuals who existed on the fringes of Victorian society. For a brief period in the $1840 \mathrm{~s}$ and $1850 \mathrm{~s}$, due to their efforts, it became more acceptable for people to speak publicly about reproductive control.

Owen's Moral Physiology mentioned a few methods of contraception and dismissed any but withdrawal, despite the "sacrifices" involved. ${ }^{2}$ Owen rejected other methods such as the sponge, partial withdrawal, or the condom as being either not

\footnotetext{
${ }^{1}$ Rilma Buckman, "Social Engineering: A Study of the Birth Control Movement," Social Forces 22 (1944): 425.

${ }^{2}$ Norman Himes, Medical History of Contraception (New York: Gamut Press, 1963), 224.
} 
effective or inconvenient. ${ }^{3}$ Owen's pamphlet was followed by Charles Knowlton's Fruits of Philosophy or, The Private Companion of Young Married People in 1832. Published anonymously, Fruits of Philosophy was the first piece of literature about contraception written by a physician. Knowlton's publication differed from Owen's because Knowlton not only advocated a different method but because he explained how to use that method. In Fruits of Philosophy Knowlton recommended that women cleanse with a solution of alum, water, sulphate of zinc, saleratus, vinegar, and chloride of soda two to three times after intercourse. ${ }^{4}$ Critics labeled Knowlton's book indecent and obscene because it promoted "illicit sexual relations" and the police arrested Knowlton for obscenity in $1832 .{ }^{5}$ After Knowlton's arrest a new edition was published in 1833 that carried his name. Despite the accusation of obscenity and indecency Knowlton's book went through several editions and by 1881 had sold 277,000 copies.

This introduction examines the actions contraceptive advocates in the nineteenth century took to educate Victorian couples on how to control their reproduction. They published pamphlets, wrote books, and gave lectures all of which met a demonstrated desire by Victorian couples to limit their family size, but they also challenged accepted reproductive practices until a large and powerful section of society stood up in opposition. This introduction, therefore, also examines the nature of that opposition and it successes and its failures, because even when the opposition succeeded in criminalizing contraceptive literature it did not succeed in

\footnotetext{
${ }^{3}$ Ibid., 225.

${ }^{4}$ Ibid., 228.

${ }^{5}$ Michael Grossberg, Governing the Hearth: Law and the Family in Nineteenth-Century America (Chapel Hill: University of North Carolina Press, 1985), 158.
} 
eradicating the topic. Also included in this section is a review of the historiography of reproductive control in America from the nineteenth to the twentieth century.

The second chapter examines the beginning of the twentieth century birth control movement under the direction of two individuals: Margaret Sanger and Mary Ware Dennett. Both women dedicated themselves to birth control education, to making birth control laws less restrictive, and to providing women with much needed access to reliable contraception. Although they engaged in different tactics they had similar goals in mind and their actions furthered the cause of birth control in America in the first half of the twentieth century.

Chapter three traces the development of the Kentucky Birth Control League under the direction of Jean Brandeis Tachau, as an example of the progress of the birth control movement after Margaret Sanger resigned as president of the American Birth Control League (ABCL). Chapter three also demonstrates that although the $\mathrm{ABCL}$ and its subsequent incarnations exerted minimal control over the state leagues, it did guide them in their efforts to educate the general population about birth control. Under Tachau's leadership the League extended its birth control activities outside Louisville to almost every county in the state. The League provided education and contraceptives and after the League dissolved the work it began was continued by Louisville Planned Parenthood and other clinics throughout the state.

Chapter four concludes with an overview of the direction of birth control after the national birth control organization became Planned Parenthood. Although the achievements the movement made during the Great Depression and World War 
II diminished the need for a movement designed to change public opinion and legislation, birth control made significant advancements in the decades after World War II. The most notable was the development of the oral contraceptive in the 1950s, which would not have happened without the support of Katharine Dexter McCormick.

\section{Anthony Comstock and the Criminalization of Contraception}

Contraceptive advocates in the early and mid-nineteenth century encountered little opposition and, as Janet Farrell Brodie states, after 1830 contraceptive information was not difficult to find. Women and men from all areas and classes had access to information about various contraceptive methods and in the 1830s such information became a "commercial enterprise in the expanding market economy." When opposition arose in the 1850s it came from physicians who campaigned against abortion seekers and abortionists because they opposed abortion on moral or professional grounds.

Comstock worked with the New York Society for the Suppression of Vice after the Civil War and lobbied against what he considered obscenities, which included pornography, abortion, and contraception. ${ }^{7}$ Comstock campaigned against obscenity because of his experiences during the Civil War where, for the first time, he was exposed to gambling, hard liquor, and men "indulging their sexual appetites." ${ }^{8}$ Comstock found that the goals of the Young Men's Christian

\footnotetext{
${ }^{6}$ Janet Farrell Brodie, Contraception and Abortion in Nineteenth-Century America (Ithaca: Cornell University Press, 1994), $\mathrm{x}$.

${ }^{7}$ Armond Fields, Katharine Dexter Mccormick: Pioneer for Women's Rights (Westport: Praeger, 2003), 175.

${ }^{8}$ Leigh Ann Wheeler, Against Obscenity: Reform and the Politics of Womanhood in America, 1873-1935 (Baltimore: The Johns Hopkins University Press, 2004), 10.
} 
Association (YMCA) complemented his own so he worked with the YMCA and distributed Christian material among the soldiers. After the war Comstock devoted himself to reform work, and in 1868, after the YMCA helped a bill pass New York state legislature that "prohibited the dissemination of 'obscene literature'," he started to implement it. J Janet Farrell Brodie argues that the "public visibility" of obscene literature, including literature about contraception, contributed to "Comstockery."10 According to Brodie after 1850 "many Americans" wanted to "restore American 'social purity"” and because of the increasing visibility of reproductive control it became one of the issues these Americans wanted to restrict. ${ }^{11}$ In his early career as a social reformer Comstock, however, focused his attention on the people who sold "erotic books and pictures." 12

In 1872 Comstock branched out from the world of erotic literature when he tried to arrest two women's rights advocates, Victoria Woodhull and Tennessee Claflin. They published an article in their magazine, Woodhull and Claflin's Weekly, about the alleged infidelity of Henry Ward Beecher. Comstock believed the article was obscene, but the New York state law only restricted the people who sold the obscene literature, not the people who published it. As a result of his failed attempt to arrest them Woodhull and Claflin published several articles that mocked Comstock. Comstock's inability to secure the indictment of Woodhull and Claflin

\footnotetext{
${ }^{9}$ Constance M. Chen, "The Sex Side of Life": Mary Ware Dennett's Pioneering Battle for Birth Control and Sex Education (New York: The New Press, 1996), xv.

${ }^{10}$ Brodie, Contraception and Abortion in Nineteenth-Century America, 241.

${ }^{11}$ Ibid., 253.

${ }^{12}$ Chen, "The Sex Side of Life": Mary Ware Dennett's Pioneering Battle for Birth Control and Sex Education, xv.
} 
combined with his anger at their articles about him convinced Comstock that the obscenity laws needed to be stricter. ${ }^{13}$

In 1872 Comstock took the first step to effecting stricter obscenity legislation when he suggested collaboration with the YMCA. The YMCA made him a representative of the new Committee for the Suppression of Vice and in his new position Comstock took an anti-obscenity bill to Washington, D.C., a bill that included a ban on contraception. In 1873 , Comstock succeeded when Congress passed the bill which was included in Federal Penal Code, Section 211. The law Comstock supported became known as the Comstock Act and was the first federal law in the United States about contraception and abortion. According to section 211 any publications intended to prevent conception or produce abortion or any items sent through the mail that could be used to prevent conception or produce abortion were declared "non-mailable."14

Comstock became a special agent for the United States Post Office on March 6,1873 , in order to enforce the new law. Between 1873 and 1880 Comstock contributed to the arrest and indictment of fifty-five alleged abortionists. ${ }^{15}$ Comstock's actions also caused the number of abortion advertisements to decline by the end of the 1870s. ${ }^{16}$ In 1878 Comstock arrested Madame Restell, the most infamous abortionist in New York, whose wealth from performing abortions was estimated at $\$ 1,000,000$. Mohr describes how Comstock caught Restell by posing as

\footnotetext{
${ }^{13}$ Ibid., xvi.

14 "What Congress Has Done to Date About Birth Control Legislation," Congressional Digest 10 (1931): 100.

${ }^{15}$ James C Mohr, Abortion in America: The Origins and Evolution of National Policy (New York: Oxford University Press, 1978), 97.

${ }^{16}$ Ibid., 199.
} 
a person in need of abortifacients, a tactic he often used to catch people who sold obscene literature. After Comstock purchased the abortifacients he arrested Restell, but was denied the satisfaction of seeing Restell indicted when she committed suicide while she awaited trial. ${ }^{17}$

In time, Comstock abandoned his campaign against obscene literature and abortions in favor of shutting down gambling and "illegal lotteries," but the legacy of Comstockery affected the course of reproductive control in America until the twentieth century. ${ }^{18}$ As Brodie states, despite the availability and popularity of reproductive control information few groups or individuals organized or expressed opposition to the Comstock legislation. ${ }^{19}$ Brodie believes that the "most dramatic legacy" of Comstockery and the lack of significant opposition is that information about reproductive control was driven either "underground" or "into a netherworld of back-fence gossip and back-alley abortions.",20

Though Comstock's law was the first law against contraception or abortion on the federal level, the United States, between 1860 and 1880 states had created forty antiabortion statutes. ${ }^{21}$ But Comstock paved the way for the states to pass laws with greater restrictions on reproductive control so that by the end of the nineteenth century state laws lacked the ambiguity that had characterized such legislation prior to $1860 .^{22}$ Connecticut was the first state to create a law that denied

\footnotetext{
17 Ibid.

${ }^{18}$ Ibid.

${ }^{19}$ Mary Ware Dennett later wrote about contraceptive laws and the creation of the Comstock Law, possible changes to the law, and the efficacy of abolishing the laws in Birth Control Laws: Shall We Keep Them, Change Them, or Abolish Them.

${ }^{20}$ Brodie, Contraception and Abortion in Nineteenth-Century America, 288.

${ }^{21}$ Mohr, Abortion in America: The Origins and Evolution of National Policy, 200.

${ }^{22}$ Ibid., 119 and 208.
} 
quickening doctrine, made women liable, and prohibited advertisements. Oregon became the first state to make abortion a manslaughter offense for women. ${ }^{23}$

\section{Challenging the Laws}

During the period of criminalized reproductive control only one organization campaigned against the Comstock Act. The National Liberal League organized a petition to repeal the law and collected 50,000 signatures, although, the petition failed. ${ }^{24}$ Resistance to the Comstock Act most often manifested in individuals who provided contraception or abortions despite the law. For example, in New York physician John Bott mailed contraceptive powder and was arrested, Madame Restell provided abortions until her arrest and subsequent suicide, and in 1875 , New York state convicted Dr. Edward Bliss Foote for sending contraceptive information. ${ }^{25}$ Not everyone arrested for violating the law was convicted such as Dr. Sarah Chase of Boston who was arrested for selling syringes. She was acquitted, in part, because Comstock compared her to Restell and thus led a juryman to ask Comstock if he "intended to drive Chase to suicide as well."26 Most cases, however, resulted in convictions and with no change to restrictive laws.

In addition to the individuals who provided contraceptive devices and information, physicians also published articles on the topic and thus kept the issue of reproductive control public. Norman Himes studies the literature that physicians produced about reproductive control after the 1870 s and notes that one of the first articles published after the Comstock Act passed, written by O.E. Herrick,

\footnotetext{
${ }^{23}$ Ibid., 203.

${ }^{24}$ Linda Gordon, Woman's Body, Woman's Right: Birth Control in America (New York: Penguin Books, 1974), 105.

${ }^{25}$ Grossberg, Governing the Hearth: Law and the Family in Nineteenth-Century America, 190.

${ }^{26}$ Ibid.
} 
appeared in a medical journal in $1882 .{ }^{27}$ Herrick published an article in the Michigan Medical News entitled "Abortion and Its Lesson." Herrick argued that existing laws and beliefs did not prevent abortions, but abortions could be prevented by contraceptive knowledge. ${ }^{28}$ Himes explains that Herrick believed women should want to be mothers rather than become mothers out of a sense of duty. Himes also discusses Dr. Ernest Helm who argued, in a symposium in the Medical and Surgical Reporter in 1888 , those women who married young or in ill health should put off conception until such a time when they could be better mothers. Helm believed that physicians who argued that contraception was a crime that "open the floodgates of immorality" needed to put themselves in the "place of the heavily-burdened woman. ${ }^{, 29}$ Illegality did not prevent the practice or discussion of reproductive control, it did not stop women from wanting to control when they had children, and it did not stop sympathetic physicians from providing the means, but a belief in the necessity and importance of contraception did not equate to a movement to change the status quo.

By the early twentieth century President Theodore Roosevelt contributed to renewed opposition to a practice that continued despite the laws when he condemned contraception and the women who wanted to control family size for contributing to race suicide. Race suicide was the belief that immigrants, poor, and non-whites would overtake the "Yankee" population and people concerned with the decrease in the "Yankee" population believed that birth control was a "rebellion" by

\footnotetext{
${ }^{27}$ Norman Himes, Medical History of Contraception (New York: Gamut Press, 1963), 286.

${ }^{28}$ Ibid., 287.

${ }^{29}$ Ibid., 294 and 295.
} 
women against "their primary social duty—motherhood." ${ }^{30}$ People feared race suicide criticized privileged and educated women for contributing to it because they had the most access to contraception, but were the type of people who should be building the population. ${ }^{31}$ For five years, from 1905 to 1910 , race suicide was a powerful raison d'etre for those who opposed the practice of contraception. In 1909 opposition succeeded in effecting even stricter laws when Congress passed an act that criminalized transporting or importing obscene literature across state lines. Section 245 of the criminal code made it illegal for anyone to import materials from a foreign country that could be used to prevent conception.

Three years after Congress enacted stricter legislation Margaret Sanger decided to change the status of contraception from an obscene to an accepted practice. Her nineteenth century predecessors laid the foundation by making reproductive control a public issue and ensuring that even when it was illegal it was not unknown. Where they challenged the norm Sanger changed it. Sanger wanted to make contraception publicly, legally, and medically acceptable by educating the public and challenging the laws. She engaged in activities designed to draw public attention to the issue. Sanger believed she started the "battle against Comstock's obscenity laws utterly alone" because she purposely challenged the laws, unlike nineteenth century contraceptive advocates, but she was not alone for long. ${ }^{32}$ Others joined Sanger who believed that women had a right to control their

\footnotetext{
${ }^{30}$ Gordon, Woman's Body, Woman's Right: Birth Control in America, 134.

${ }^{31}$ Ibid., 136.

${ }^{32}$ Margaret Sanger, My Fight for Birth Control (New York: Maxwell Reprint Company, 1931), 80.
} 
reproduction for their "health, happiness and liberty" in the name of voluntary motherhood. ${ }^{33}$

The twentieth century birth control movement, led by Sanger, built upon the work begun by Robert Dale Owen, but Owen's successors never coalesced into an organized movement with specific objectives while Sanger and her colleagues did. Every thing Sanger did was done to educate the public, to make birth control legal, and to ensure that every woman who wanted to control her reproduction could do so freely and openly. The tactics used in the twentieth century were reminiscent of those used in the nineteenth century: they published pamphlets, gave lectures, mailed information, but Sanger and her cohort went further; they created an organization to achieve their goals, they opened clinics, they went to court and they went to Congress. Sanger started the movement, but it was through more than just her efforts that birth control became an acceptable practice because she started a movement that spread to every state where like-minded individuals implemented her ideas and brought birth control to the masses.

\section{Historiography}

One of the first scholarly works that examined the history of contraception, including a review of existing literature, was Medical History of Contraception originally written in 1936 by Norman E. Himes. ${ }^{34}$ Although Himes was not a medical doctor one reviewer considered Medical History of Contraception the best

\footnotetext{
${ }^{33}$ Frederick Blossom Margaret Sanger, Elizabeth Stuyvesant, "To the Men and Women of the United States," The Birth Control Review 1 (1917): 2.

${ }^{34}$ Himes often contributed articles to the Birth Control Review, including an article in November 1929 in which he discussed the future of the birth control movement and placed initiation of the movement with Robert Dale Owen (Birth Control Review, November 1929, 317).
} 
"contribution to the subject of contraception." 35 Himes demonstrates that the desire to control conception existed in many cultures for many centuries. Himes mentions an anonymous pamphlet published in the later half of the nineteenth century in which the author contended that the use of contraception was necessary in the case of multiple abortions, miscarriages, or when a woman consistently failed to give birth to a living child. ${ }^{36}$ The author also argued that physician's had a moral imperative and a duty to inform such women of contraceptive methods because it was better to prevent the need for operations that harmed mother or child. ${ }^{37}$

Himes also discusses Edward Bliss Foote's contribution to contraceptive literature including Medical Common Sense in 1858 and Words in Pearl in which Foote explained the possible reasons why women practiced contraception. ${ }^{38}$ Foote believed that women used contraception if they had health problems, "predisposition to insanity," deformities, or if they lived in poverty. ${ }^{39}$ Foote's reasons for why women might use contraception, the implication that they would not want to pass on insanity or physical problems, indicated a eugenics approach to reproduction. ${ }^{40}$ Foote and Anonymous made arguments used by people in the twentieth century birth control movement, including Himes in his 1929 Birth Control Review article. ${ }^{41}$

Janet Farrell Brodie provides a more recent in-depth analysis of nineteenth century reproductive literature in her 1994 book, Contraception and Abortion in

\footnotetext{
${ }^{35}$ J.P. Greenhill, "Medical History of Contraception," The Journal of Political Economy 45 (1937): 132.

${ }^{36}$ Himes, Medical History of Contraception, 281.

${ }^{37}$ Ibid.

${ }^{38}$ No copy of Words In Pearl exists today.

${ }^{39}$ Himes, Medical History of Contraception, 277.

${ }^{40}$ Ibid.

${ }^{41}$ Norman Himes, "Next Steps in the Movement," Birth Control Review (1929): 318.
} 
Nineteenth-Century America, published by Cornell University Press. Brodie examines the reproductive literature produced after the 1830s and how it contributed to discussions about contraception becoming more public and thus more acceptable. She argues that public lectures about reproductive control helped legitimize the subject because of lecturers like Frederick Hollick who lectured with "properly restrained delivery ... with carefully chosen language." ${ }^{, 42}$ In addition to lectures Hollick published Marriage Guide or Natural History of Generation in which he discussed various contraceptive methods from withdrawal to condoms.

Brodie describes the actions of Frances Wright because she believes that women who lectured about topics other than slavery, temperance, and moral reform have been ignored by historians. Although she admits information on the content of lectures given by women is difficult to find she believes Wright's story is "worth telling ... because it reflects, at the extreme, the dilemmas and constraints other women faced. ${ }^{43}$ Brodie's discussion of Frances Wright and other "spokeswomen" for reproductive control demonstrates that while not every nineteenth century man or woman believed it was a woman's right to control her reproduction some did and they helped make the topic acceptable. ${ }^{44}$

Brodie also examines the people who made it possible for the general public to have access to reproductive literature. Liberal-minded men like Abner Kneeland, Augustus and George Matsell, and Gilbert Vale published editions of books about reproductive control including Charles Knowlton's Fruits of Philosophy and Robert Dale Owen's Moral Physiology. Thomsonians and other "irregular"

\footnotetext{
${ }^{42}$ Brodie, Contraception and Abortion in Nineteenth-Century America, 113.

${ }^{43}$ Ibid., 120.

${ }^{44}$ Ibid., 125.
} 
physicians also popularized reproductive control and advised women on various methods. Thomsonians encouraged their female patients to discuss and learn about their reproductive health and in doing so they could learn to control fertility. Brodie states that some regular physicians opposed reproductive control, but during the 1830s such opposition did not prevent literature from reaching a wide audience of men and women from urban and rural areas. ${ }^{45}$ By the mid-nineteenth century discussions about sex and reproduction were more public and men and women were more aware of reproductive issues. ${ }^{46}$

Historian James Mohr also examines the effect of physicians' opposition to reproductive control and the American Medical Association's (AMA) successful campaign against abortion in Abortion in America: The Origins and Evolution of National Policy (1978). Mohr argues that the AMA's campaign against abortion inspired the involvement of other groups, specifically supporters of the antiobscenity movement, which opposed more than just abortion. ${ }^{47}$ The most notable and influential of these reformers was Anthony Comstock who made a name for himself as a social reformer who campaigned against obscenity in the 1860s-1890s after the end of the Civil War.

While men and women such as Owen, Knowlton, Hollick, and Wright lectured and produced literature, women in the growing women's rights movement of the 1840 s also began to speak about "their unhappiness with the entire sexual system." ${ }^{48}$ Feminists, however, did not develop a specific contraceptive ideology

\footnotetext{
${ }^{45}$ Tbid., 168.

${ }^{46}$ Ibid., 135.

${ }^{47}$ Mohr, Abortion in America: The Origins and Evolution of National Policy, 196.

${ }^{48}$ Gordon, Woman's Body, Woman's Right: Birth Control in America, 90.
} 
until the $1870 \mathrm{~s} .{ }^{49}$ The voluntary motherhood movement of the 1870 s gave the wife the ultimate power to control her reproduction; reproduction she controlled by practicing abstinence rather than using artificial means to prevent conception.

A study of the voluntary motherhood movement as a women's rights issue and social movement can be found in Linda Gordon's Woman's Body, Woman's Right: Birth Control in America (1974) and later in The Moral Property of Women: A History of Birth Control Politics in America (2002). Gordon argues that because "efficient birth control" would have allowed men to engage in extramarital sex while societal constraints would have prevented women from doing the same "we must discard the twentieth-century association of birth control with ... sexual freedom. ${ }^{, 50}$ Instead voluntary motherhood reinforced sexual morality and purity because society encouraged women to marry and become mothers. Moreover, the social purity movement reinforced the connection between sex and marriage because social purists wanted to "abolish prostitution and other sexual philandering," although it also "contributed to the acceptance of birth control" according to Gordon. ${ }^{51}$

In Woman's Body, Woman's Right, Linda Gordon also examines the positive and negative influence of race suicide on the future birth control movement. According to Gordon, one of the long term effects of the accusation that woman contributed to race suicide was that it caused many more feminists and professional

\footnotetext{
${ }^{49}$ For the purpose of this thesis feminist applies to women who advocated for women's rights.

${ }^{50}$ Linda Gordon, The Moral Property of Women: A History of Birth Control Politics in America (Chicago:

University of Illinois Press, 2002), 67.

${ }^{51}$ Ibid., 72.
} 
women to commit "themselves publicly and lastingly to birth control."52 The women who defended their right to control their reproduction in the face of Theodore Roosevelt's condemnation contributed to the creation of the twentieth century birth control movement. Gordon argues, however, that the increased defense of contraception had a negative impact as well. The involvement of professionals and feminists underscored the differences between feminists and the poor and working classes. According to Gordon, feminists saw birth control as a way for women to have careers and obtain higher education; options poor women did not have even if they used birth control. ${ }^{53}$

In 2002 Linda Gordon published The Moral Property of Women: A History of Birth Control Politics in America, which is an updated edition of her 1976 book Woman's Body, Woman's Right. Gordon provides a survey of the "general history of birth control politics in the United States." 54 Gordon tells the story of the "eventual widespread public acceptance of birth control" from the point of view of women who sought "sexual and reproductive self-determination." 55 Gordon contends that birth control only became a social movement when people developed "collective strategies," and once it did it went through four stages characterized by the slogans of "voluntary motherhood," birth control," "planned parenthood," and "reproductive rights." "56

Gordon focuses on the birth control movement from the mid-nineteenth to the late-twentieth century, but she begins part one with an examination of the

\footnotetext{
${ }^{52}$ Gordon, Woman's Body, Woman's Right: Birth Control in America, 154.

${ }_{54}^{53}$ Ibid.

${ }^{54}$ Gordon, The Moral Property of Women: A History of Birth Control Politics in America, 1.

${ }_{55}^{55}$ Ibid.

${ }^{56}$ Ibid., 3 and 4.
} 
history of reproductive practices prior to the movement in order to understand the various struggles of the movement by learning about the "nature and sources of the censoring ideology." ${ }^{, 57}$ Gordon argues that birth control was "widely practiced in pre-agricultural and nomadic societies" even though there has always been opposition to birth control because of its connection to the status of women. ${ }^{58}$ After a discussion of the birth control methods available from infanticide to intrauterine devices Gordon concludes that "involuntary childbearing" was a result not of the lack of technology but because the technology was suppressed. ${ }^{59}$ Gordon also examines the women who practiced reproductive control in the nineteenth century even when the methods they practiced were illegal. Gordon argues that reproduction and reproductive control was a common experience among women regardless of class that created a connection that ended when the birth control movement began because it was not about that common experience anymore. ${ }^{60}$ Gordon also examines how the birth control became transformed from a women's rights issue to a movement about family planning. After WWI the birth control movement changed because it became "an increasingly centralized and professional campaign. ${ }^{, 61}$ The movement became centralized and professional because the dominant strategies of the movement of "opening clinics and lobbying for legislation" required the money and support of the wealthy who then gained power within the movement. ${ }^{62}$ The Great Depression further encouraged people to

\footnotetext{
${ }^{57}$ Ibid., 7.

${ }^{58}$ Ibid., 8

${ }^{59}$ Ibid., 21.

${ }^{60}$ Ibid., 37.

${ }^{61}$ Ibid., 172.

${ }^{62}$ Ibid.
} 
seek family limitation but it did not cause the movement to grow; the movement remained dominated by professionals, the wealthy, and "middle-class reformers.",63 Gordon argues that the economic problems of the Depression changed the ideology of the movement from one that emphasized reducing the "population of the inferior" to reducing poverty through family limitation. ${ }^{64}$ By 1942 the birth control movement embraced the idea of family planning and limitation as the "new concept of birth control" when the birth control movement became the Planned Parenthood Federation of America. ${ }^{65}$ Gordon argues that Planned Parenthood "further separated birth control from any remaining feminist orientation" because it created a relationship between birth control and "mainstream social planning."

Population control and the development of the birth control pill further changed the shape of the birth control movement after WWII. Gordon does not retell the story of either because she believes they have been recounted well by other authors but she does seek to put into a "long-term historical perspective" and "to call attention" to how both developments "altered the very meanings of birth control." ${ }^{97}$ Gordon demonstrates how during the 1950 s population control and the pill changed birth control by explaining how eugenics "took over" population control and subsequently Planned Parenthood when Margaret Sanger asked the Brush Foundation to fund the International Planned Parenthood Federation with

\footnotetext{
${ }^{63}$ Ibid., 211.

${ }^{64}$ Ibid.

${ }^{65}$ Ibid., 242.

${ }^{66}$ Ibid., 278.

${ }^{67}$ Ibid., 279.
} 
headquarters provided by the English Eugenics Society in London. ${ }^{68}$ Gordon believes that the birth control pill was the "child" of the alliance between birth control and population control because it was created as a more efficient way to solve the population control problem, but she also believes that women reclaimed the pill as a "tool for autonomy, freedom, and higher aspirations." ${ }^{69}$ Gordon argues that birth control is best understood in a political context and that the influence of eugenics, professionals, and population control changed the shape of the birth control movement.

According to social historians John D'Emilio and Estelle Freedman in Intimate Matters: A History of Sexuality in America, prostitution, once considered a "necessary evil," came under attack from middle-class reformers after the 1830 s because it represented both real and imagined threats to themselves and their families. ${ }^{70}$ D'Emilio and Freedman further explain why abstinence was the only form of contraception supported by the voluntary motherhood movement.

According to them prostitution contributed to fears about disease and represented the "extreme case of the separation of sexuality, not only from reproduction, but also from love and intimacy." purity and chastity by campaigning against acts that challenged these ideas, they did

\footnotetext{
${ }^{68}$ Ibid., 281. David Goldstein wrote unfavorably of Sanger Suicide Bent: Sangerizing Mankind while David Kennedy was more favorable to Sanger and her contributions in Birth Control in America: The Career of Margaret Sanger.

${ }^{69}$ Ibid., 288.

${ }^{70}$ John and Estelle B. Freedman D'Emilio, Intimate Matters: A History of Sexuality in America (New York: Harper and Row Publishers, 1988), 141.

${ }^{71}$ Ibid.
} 
not deny female sexuality. Nor did they advocate sex outside of marriage because they saw it as a threat to their identities. ${ }^{72}$

In addition to these scholarly works more recent scholarship has been produced including Johanna Schoen's Choice and Coercion: Birth Control, Sterilization, and Abortion in Public Health and Welfare, which is an examination of reproductive control in America in the twentieth century. Schoen wrote her book after she gained access to North Carolina's Eugenics Board records in the state archives, which she had originally found when researching her dissertation, but did not receive full access to until 1996. While the book grew out of the information she found in these archives Schoen also used several other archives, newspapers, and secondary sources. Schoen studies the twentieth century history of reproductive control in North Carolina. Schoen wrote her book to "give voice to a group of women who are usually rendered silent" but who also wanted reproductive control. ${ }^{73}$ Schoen believes that the result of her interpretation of the sources she used and the stories she tells "competes with other interpretations about the errors and lessons of this history."

Schoen's primary goal is to examine the impact of state control on reproductive control for women. She argues the state both gave women greater control than before, but also could control women's reproduction, because it determined who received birth control, sterilization, or abortion. In particular she

\footnotetext{
${ }^{72}$ Ibid., 145.

${ }^{73}$ Gordon, The Moral Property of Women: A History of Birth Control Politics in America, 1. Johanna Schoen, Choice and Coercion: Birth Control, Sterilization, and Abortion in Public Health and Welfare (Chapel Hill: The University of North Carolina Press, 2005), xi.

${ }^{74}$ Schoen, Choice and Coercion: Birth Control, Sterilization, and Abortion in Public Health and Welfare, 19.
} 
focuses on poor women with limited resources whom the state "alternately offered and denied ... access to birth control, sterilization, and abortion." ${ }^{.75}$ Poor women wanted reproductive control, but in North Carolina they rarely practiced such control "on their own terms." sought reproductive control or the reasons they were offered birth control services they "had to negotiate with health and social work professionals for access to reproductive control." ${ }^{, 77}$ Schoen also contends that public opinion about reproductive rights as they pertain to poor women has changed little in the last five decades and that before opinion changes the right of women to reproductive control regardless of age race, class, or marital status has to be acknowledged. ${ }^{78}$

This thesis does not dispute the importance of understanding birth control in its political context nor does it dispute that the associations the movement made with other groups changed the birth control movement; instead, the intention is to show that Sanger and her cohort expanded upon nineteenth century efforts to provide people reproductive control. The twentieth century political and economic environment influenced the birth control movement, but key individuals navigated the environment and developed a program of dissemination and education that furthered the cause of birth control.

\footnotetext{
${ }^{75}$ Ibid., 2

${ }^{76}$ Ibid., 3 .

${ }^{77}$ Ibid., 235.

${ }^{78}$ Ibid., 250.
} 


\section{CHAPTER TWO: ORGANIZING FOR BIRTH CONTROL}

Raise your voice, strong, clear, fearless, unconditionally pledged to the protection of womanhood, uncompromisingly opposed to those who, to serve their selfish ends, would keep her in ignorance and exploit her finest instincts. $^{79}$

Contraceptive advocates of the twentieth century succeeded where their nineteenth century predecessors failed. What distinguished twentieth century contraceptive advocates from those of the nineteenth century is that by 1915 a national organization existed to coordinate efforts to increase awareness of contraception, advance knowledge of contraception, and to challenge the laws that prevented people from obtaining or learning about contraception when they wanted and needed it. Whereas the primary objective of nineteenth century advocates was not to change laws but to provide contraceptive information to those who wanted it, in the twentieth century rather than continue to sell and mail contraception and risk the legal consequences birth controllers organized a campaign specifically designed to challenge the laws. Margaret Sanger and Mary Ware Dennett wanted to provide contraception but they believed that laws and public perception had to change before they could achieve success in providing birth control to all married women who wanted it for any reason. Sanger and Dennett engaged in different tactics to achieve similar goals. They made birth control an issue that the

\footnotetext{
${ }^{79}$ Margaret Sanger, "To the Men and Women of the United States," 2.
} 
public could not ignore and succeeded in creating a movement that grew and survived without them.

\section{Margaret Sanger's Early Career}

Margaret Sanger's long and varied birth control career began when she published The Woman Rebel in 1914, a newspaper that discussed marriage, birth control, and challenged contraceptive laws. Sanger's experiences as an obstetrics nurse in New York and her mother's eleven births, which Sanger blamed, in part, for her mother's death at forty-eight, piqued Sanger's interest in contraception. ${ }^{80}$ After her mother's last conception, subsequent illness, and death Sanger's interest in nursing increased and she trained at a small hospital near New York City. By 1912, although Sanger's marriage, three children, and bout with tuberculosis decreased the time she devoted to nursing she accepted individual obstetric cases and visited the homes of poor women when it was time for them to give birth. ${ }^{81}$ The women she encountered on these visits were desperate for ways to prevent conception that worked, often after having resorted to illegal abortions or dangerous home remedies. ${ }^{82}$ Sanger wanted to help these women who had been denied contraceptive knowledge by their physicians, midwives, or social workers. But, at this time she only knew of two methods of contraception most often used by middle class women, coitus interruptus and the condom, but the women Sanger encountered disregarded these methods because they relied on their husbands to take responsibility. ${ }^{83}$

\footnotetext{
${ }^{80}$ Sanger, My Fight for Birth Control, 4.

${ }^{81}$ Ibid., 46.

${ }^{82}$ Remedies varied from drinking herbal teas to using knitting needles to induce abortions.

${ }^{83}$ Margaret Sanger, Margaret Sanger: An Autobiography (New York: W.W. Norton \& Co., 1938 ), 87.
} 
Her inability to help these women angered and frustrated Sanger, but it was not until she witnessed Sadie Sachs' situation that she decided to do something. Sadie Sachs was a twenty-eight year old mother of three who performed a selfabortion, which caused an illness that required the services of Sanger. Sachs recovered from her illness terrified of having another child, but her physician told her if she wanted to prevent conception she should make her husband "sleep on the roof'." ${ }^{84}$ Three months after she first met Sadie Sachs Sanger was called again by her husband after Sadie first performed another self-abortion using drugs and then procured one from a "five-dollar professional abortionists" when her own attempt failed. ${ }^{85}$ Sachs' subsequent death was the catalyst for Sanger's decision to dedicate her life to providing every woman with contraceptive knowledge. ${ }^{86}$

Sanger found, however, that physicians proved uncooperative due to the restrictions against contraception imposed by the Comstock law. The "progressive women" Sanger approached told her to wait until women had the vote, women had more education, or until the gap between wealthy and poor was smaller. ${ }^{87}$ The Comstock law also made it difficult for Sanger to find for herself the information she wanted and she found the libraries she visited lacking. In 1913 Sanger, along with her husband and three children, left for Europe where she hoped to discover useful contraceptive information. In France Sanger learned that knowledge of douches and suppositories was passed from mother to daughter, but as in America

\footnotetext{
${ }_{85}^{84}$ Sanger, My Fight for Birth Control, 53.

${ }^{85}$ Ibid., 54.

${ }^{86}$ Sanger, Margaret Sanger: An Autobiography, 91.

${ }^{87}$ Sanger, My Fight for Birth Control, 57.
} 
French physicians did not teach women about contraception. ${ }^{88}$ Sanger returned to America as frustrated as when she left with the state of contraception and still unable to procure the support of any organization because of the Comstock law.

Sanger resolved to challenge the Comstock law on her own. Her first step was to publish The Woman Rebel to challenge the laws against contraception. More than a test of how far she could go in challenging Comstock, The Woman Rebel was Sanger's call to arms designed to elicit support; support Sanger obtained when she "received over 10,000 requests for contraceptive information." 89 The first issue of The Woman Rebel, published March 1914, was inflammatory. Sanger challenged women to "think for themselves and to build up a conscious fighting character." The Woman Rebel advocated contraception for poor women who did not have access to reliable contraception like their middle and upper-class counterparts, in defiance of the law. Sanger received the response she hoped for when the New York postmaster informed her that The Woman Rebel was unmailable.

Sanger was not arrested, but she was warned against future publications even though the postmaster did not tell her which articles constituted a violation of the law. Sanger excoriated the postmaster and the law in the April issue of The Woman Rebel for suppressing free speech and contributing to ignorance about "sexual hygiene." "1 At this time Sanger had also been working on Family Limitation, the first advice pamphlet she wrote to relieve ignorance about birth control. Sanger hoped that if she discussed birth control, a phrase first coined in the pages of The

\footnotetext{
${ }^{88}$ Ibid., 73.

${ }^{89}$ Ibid., 81.

${ }^{90}$ Margaret Sanger, "The Aim," The Woman Rebel, March 1914, 1.

${ }^{91}$ Margaret Sanger, "Humble Pie," The Woman Rebel, April 1914, 1.
} 
Woman Rebel, in a simple scientific manner then more people would be convinced that the subject was not obscene. The pamphlet was not distributed before she was arrested, however.

Sanger published issue after issue of The Woman Rebel despite the warnings she received until she was indicted for articles in the March, May, and July issues. With the exception of the article entitled "A Defense of Assassination" each article related to birth control or abortion. Sanger was willing to go to prison for her beliefs, but she did not want to go to prison with the public believing she advocated the obscene; she did not want to be "misunderstood." 92 If she went to prison for publishing obscenity rather than for challenging an unjust and harmful law then every thing she had done up to that point was meaningless. Sanger traveled to Europe until the war ended since she did not have enough time to mount an adequate defense that would convince judge, jury, and the public that she did not peddle obscenity.

Sanger's second European trip she increased her knowledge of European birth control practices and implemented what she learned when she returned to the United States. In Europe, where she learned about the French pessary and diaphragm, Sanger also visited the Netherlands. Sanger's experience in the Netherlands altered her perceptions about birth control and affected her actions in American after she returned. Sanger believed birth control freed working class women from having more children than they wanted or could care for. While her experience with Sadie Sachs convinced her that it was better to prevent conception

\footnotetext{
${ }^{92}$ Sanger, My Fight for Birth Control, 92.
} 
than force women to obtain illegal and harmful abortions, the Netherlands' statistics provided evidence.

In the Netherlands Sanger learned that while the population increased infant and maternal mortality decreased as did instances of venereal disease and abortion; results she attributed to the prevalent use of contraception in the Netherlands. Women in the Netherlands most often used diaphragms, which trained professionals provided, but women also had access to fifty clinics where trained nurses or midwives provided birth control instruction. Whether or not birth control was solely responsible, Sanger believed a correlation existed between the clinics "endorsed by the Neo-Malthusian League," which provided individual contraceptive instruction, and the Netherlands' decreased birth rates, infant and maternal mortality rates, and abortion rates. ${ }^{93}$ Sanger attributed the increased population to the practice of child spacing, which allowed the population to increase but not at such a rate that hindered the "livelihood" of "those already born." "94 Sanger's experiences in the Netherlands changed the course of the American birth control movement. Sanger dedicated herself to providing women with birth control, but also to making sure only physicians had the legal ability to disseminate birth control because she believed physicians were the most qualified to do so in a safe and effective manner. Sanger, however, did not organize the first national birth control organization; Mary Ware Dennett did when she organized the National Birth Control League in 1915 while Sanger was in Europe. ${ }^{95}$

\footnotetext{
${ }^{93}$ Ibid., 110.

${ }^{94}$ Ibid., 112.

${ }^{95}$ David J Garrow, Liberty and Sexuality: The Right to Privacy and the Making of Roe V. Wade (New York: MacMillan Publishing Company, 1994), 11.
} 


\section{Mary Ware Dennett}

Dennett and Sanger had two very different childhoods, but both were influenced by their parents' experiences. Sanger grew up in the factory district of Corning, New York the sixth of eleven children born to poor parents. Dennett was born into an upper-class New England family. Sanger watched her mother grow weaker with each pregnancy until she died at the age of forty-eight. Dennett's mother, Livonia Coffin Ames, bore only four children; the first not until five years after her marriage to George Whitfield Ware.

Dennett's parents provided an example of two people who married not because society dictated it or for money, but for romantic love. Dennett's mother and two aunts rejected marriage as an institution they had to join for security and chose independence instead. One aunt never married, and the other pursued a career as a teacher, lecturer, and writer before she married late in life. Like Sanger's parents Dennett's experienced economic difficulties, but they waited five years to have children and then only had four in comparison to Sanger's father who supported eleven children as a sculptor. When Dennett's father died her mother supported the family by taking young women on European tours. Dennett, therefore, grew up with her mother and aunts as examples of women who flouted convention. ${ }^{96}$

Dennett followed in their footsteps when she continued her education and attended art school in Boston rather than choosing a more traditional female vocation. In 1900, Dennett also followed in her mother's example when she married

\footnotetext{
${ }^{96}$ Chen, "The Sex Side of Life": Mary Ware Dennett's Pioneering Battle for Birth Control and Sex Education, 6.
} 
William Hartley Dennett for love. The Dennett's had three children, the second died at three weeks, and each birth was difficult for Dennett and after the third her doctor warned against another conception. While Sanger's desire for contraceptive knowledge was the result of her mother's experience and the women she encountered as a nurse Dennett's was the result of her own experience. The doctor told her she should have no more children, but he did not and could not provide her with any means to prevent conception because of the laws. The only option available to Dennett and her husband was abstinence; an undesirable method for a couple who married out of love and saw intercourse as a manifestation of that love. ${ }^{97}$

Abstinence, however, was the least of Dennett's marital problems by 1907 . In 1907 Dennett received an operation to repair a tear caused by childbirth, a tear discovered seven months after her last child was born, which required her to spend several weeks away from her children and husband. While Dennett recovered from her operation her husband developed a close relationship with a married family friend that put further strain on their marriage. When Dennett fought her husband for custody of their children he refused to provide any monetary support for her or the children. To support herself and her children and to pay the bills Dennett accepted a position with the Massachusetts Suffrage Association. ${ }^{98}$ In 1910 Dennett moved to New York to work with the National American Woman Suffrage Association (NAWSA) where she worked with the Literature Department.

Dennett's work with the NAWSA was beset by differences of opinion between Dennett and other board members. Dennett wanted to enact changes she

\footnotetext{
${ }^{97}$ Ibid., 56.

${ }^{98}$ Ibid., 105.
} 
believed would increase the success of NAWSA such as requiring a monthly instead of yearly meeting of all board members and allowing open membership for local suffrage organizations. The rest of the board opposed Dennett's revised constitution. Dennett's frustration with the conservatism of the NAWSA prompted her resignation, but in 1912 the board elected a new Congressional Committee chair, Alice Paul, who "impressed" Dennett with her "federalist approach" and Dennett returned as secretary of the NAWSA. ${ }^{99}$ As secretary Dennett was in charge of propaganda for the NAWSA, which meant she wrote as well as distributed literature for the organization. One of the articles Dennett wrote was on the subject of parenthood in which she stressed the importance of education and an equal partnership between both parents. Dennett's frustration with the organization, however, continued and increased with what she believed was the mismanagement of the budget for her department and in 1914 she resigned from NAWSA.

After her resignation from the NAWSA Dennett became involved with various radicals who had different ideas about sex, marriage, and the family. Dennett was exposed to the ideas of Sigmund Freud and Havelock Ellis, she met people who advocated free-love, a subject her NAWSA colleagues shied away from, and she learned more about birth control. Dennett's own experience with abstinence convinced her that complete abstinence harmed marriage and that some form of contraception was necessary for women who lived in fear of constant pregnancies and thus engaged in abstinence to the potential detriment of their marriages. $^{100}$

\footnotetext{
${ }^{99}$ Ibid., 143.

${ }^{100}$ Ibid., 160.
} 
In 1914 Dennett heard Margaret Sanger speak about birth control for the first time at a Heterodite meeting in Greenwich Village. Heterodites were radical feminists who gathered regularly to discuss the "cultural issues of the day." control appealed to the Heterodite commitment to female independence because it removed the fear of an unwanted and unplanned pregnancy that prevented a woman from doing her "life's work." Dennett's associates and fellow Heterodites supported birth control, but they did not support Sanger as a potential leader of a "major campaign" because they doubted she had the "organizational skills" to lead such a campaign. ${ }^{102}$ Dennett, however, later met privately with Sanger and discussed birth control, although Dennett chose not to get publicly involved with Sanger's campaign at that time.

Although Dennett chose not to join Sanger's campaign she remained interested in the topic of birth control and sex education, especially when her oldest son asked her questions about sex for which she had no answers. Dennett conducted an examination of available sex education literature, but like Sanger and her search for decent contraceptive information, Dennett found available literature lacking. She was disappointed in the vague and negative treatment of sex so she resolved to write her own literature that she gave to her sons to "demystify sex and sexuality."103

The Sex Side of Life: An Explanation for Young People was written for her own children because she believed that all the current literature about sexual matters

\footnotetext{
${ }^{101}$ Ibid., 157.

${ }^{102}$ Ibid., 163.

${ }^{103}$ Ibid., 172.
} 
available was "misleading." 104 Dennett turned the essay into a pamphlet designed for other children beside her own when she entered it into an American Social Hygiene Association contest for best sex education pamphlet. ${ }^{105}$ Dennett used physiological and scientific terminology to remove the embarrassment associated with the topic, but she also emphasized the emotional aspect of sex that occurred when two people were in love and married. Dennett mentioned that while the process of labor was painful for the woman, she believed that increased understanding of the process of child-birth would make it painless. Pain free child birth was a personal desire of Dennett's due to her three painful labors, and she cofounded the Twilight Sleep Association that researched the use of anesthesia during child birth. Although The Sex Side of Life was primarily a sex education essay Dennett briefly touched on the idea of birth control when she spoke of the future as a time when child birth would be painless and women would have the knowledge to have children "only when they want them and can afford them."106

The same year Dennett wrote The Sex Side of Life her path, albeit indirectly, crossed Margaret Sanger's again. While Sanger was in Europe evading arrest her husband was arrested for distributing a copy of Sanger's pamphlet Family Limitation. William Sanger's arrest incited pro-birth control sentiment among radicals including Mary Ware Dennett. Committees organized around the question of what to do about William Sanger's arrest and discussed raising funds for his defense. Out of these informal discussions about William Sanger's situation the

\footnotetext{
${ }^{104}$ Mary Ware Dennett, The Sex Side of Life: An Explanation for Young People (Mary Ware Dennett, 1928).

${ }^{105}$ Chen, "The Sex Side of Life": Mary Ware Dennett's Pioneering Battle for Birth Control and Sex Education, 176.

${ }^{106}$ Dennett, The Sex Side of Life: An Explanation for Young People, 7.
} 
radicals made a decision to organize a national campaign to change the birth control laws.

After William Sanger's arrest Dennett's belief that birth control needed to be legal and available increased, but she encountered the same attitudes and problems Sanger did when she approached others for support. Dennett found that suffragists, and even her twilight sleep colleagues, refrained from publicly supporting birth control. Birth control was too controversial because it implied that sex was a nonprocreative act and the dominant opinion about sex was that it was still primarily for procreation. Ideas about sex as it occurred within marriage exhibited signs of change by 1915 and even Mary Ware Dennett had discussed sex as a way for married couples to be closer, but the ultimate function of sex was still procreation. ${ }^{107}$ Sex as non-procreative was an idea better suited to the "bohemian and intellectual circles"; the circles Dennett associated with. ${ }^{108}$ Even if non-radicals agreed with Dennett, Sanger, and other radicals that birth control information should be freely available, the embarrassment associated with all topics related to sexuality had to be removed.

Dennett's experience as a leader in the NAWSA influenced her belief that the way to removing embarrassment about birth control and the way to changing the laws against it was to organize a movement with specific practices and goals. In March 1915 Dennett, with Jessie Ashley and Clara Stillman, founded the National Birth Control League (NBCL) as the first birth control organization dedicated to changing the laws. Dennett's and Sanger's approach to changing the status of birth

\footnotetext{
${ }^{107}$ Ibid., 6.

${ }^{108}$ Chen, "The Sex Side of Life": Mary Ware Dennett's Pioneering Battle for Birth Control and Sex Education, 181.
} 
control differed although they agreed on certain aspects such as the need for education, but while Sanger challenged the law by breaking it, Dennett lobbied legislators. Dennett used tactics similar to the tactics she employed as secretary of the NAWSA as secretary for the NBCL. She wrote and distributed literature designed to educate the public about the legal status of birth control and she sent New York legislators statements that refuted popular arguments against birth control. $^{109}$

Dennett argued that birth control did not subvert God's will or natural law because, like Sanger, she believed that birth control allowed women to produce healthier and wanted children and such an ability only represented the “"subordination of natural laws" inherent to civilization. ${ }^{110}$ Dennett also argued that birth control did not lead to increased immorality, but prevented occurrences of abortions, the birth of children to unfit parents, and helped the poor. Sanger and Dennett agreed on these points, but when Sanger returned to American in 1915 she and Dennett were unable to reconcile their differences. Accounts of the meeting between Sanger and Dennett upon Sanger's return differ. Sanger said that Dennett refused to aid Sanger in her legal battle against Comstock because Sanger had broken the law and the NBCL was a law-abiding organization; Dennett's biographer believed Dennett offered Sanger a position on the executive board of the NBCL, which Sanger refused because she wanted to be in control. The results,

\footnotetext{
${ }^{109}$ Ibid., 183.

${ }^{110}$ Ibid.
} 
however, are the same and Sanger and Dennett pursued different courses of action. $^{111}$

\section{Sanger's Return: A New Direction}

In the fall of 1915 Sanger returned to America upon learning of her husband's arrest. She still faced indictment for violating the Comstock laws, but had until January 1916 to prepare her case. Friends and supporters urged Sanger to change her tactics, to cease fighting for birth control in court and to "take up the legislative work," but Sanger persisted in challenging the law her way. ${ }^{112}$ In the months before the trial took place, after Sanger committed herself to her course of action, public support for her cause increased. In February 1916 New York state court dismissed Sanger's case because the prosecution did not want to expend effort in a case that could potentially make Sanger a martyr, according to David Kennedy, a Sanger biographer. It was not the victory Sanger wanted, however, because the law remained the same. ${ }^{113}$

Sanger was free to implement the knowledge she obtained while in Holland, but with a different purpose than she had before. She still believed the public needed to be educated about birth control, but before birth control had been a free speech issue and merely producing the literature and challenging the laws was enough. Sanger's experience in Holland, however, convinced her that women needed individual instruction in birth control to use it to its fullest advantage. Sanger lectured across the country about the necessity of birth control clinics that

\footnotetext{
${ }^{111}$ Sanger, My Fight for Birth Control, 125. Chen, "The Sex Side of Life": Mary Ware Dennett's Pioneering Battle for Birth Control and Sex Education, 186.

${ }^{112}$ Sanger, My Fight for Birth Control, 129.

${ }^{113}$ David M. Kennedy, Birth Control in America: The Career of Margaret Sanger (New Haven: Yale University Press, 1970), 80.
} 
provided women, mostly poor and working class, with the means to prevent conception. Sanger's lecture tour showed her that women wanted and needed birth control from New York to San Francisco and when she returned to New York she resolved to open the first free birth control clinic. ${ }^{114}$

The primary function of the clinic was the provision of contraceptive information and instruction to the poor women in the Brownsville section of Brooklyn, but the clinic was also a test case. The clinic broke the law in a more specific way than when Sanger published The Woman Rebel, which she maintained broke no law because it never provided information on preventing conception. The clinic, which provided such information, broke the New York state law that allowed only physicians to provide women with contraception if it was used to combat or prevent disease.

Although Sanger left Holland convinced the diaphragm was the best method of birth control if provided by a trained physician, because diaphragms needed to be fitted on an individual basis, when she opened the Brownsville clinic physicians were unwilling to cooperate; therefore, Sanger and Ethel Byrne, also a nurse and Sanger's sister, demonstrated how to use contraception themselves. Sanger was not a physician nor did she wish to provide birth control just to prevent disease, but she, with Byrne and Fania Mindell, also a nurse, defied the law and opened the clinic 16 October 1916. For ten days the clinic operated out of 46 Amboy Street and disseminated birth control information to the poor women of Brownsville and

\footnotetext{
${ }^{114}$ Sanger, My Fight for Birth Control, 150.
} 
neighboring areas. On the first day forty-five women lined up and visited the clinic desperate for a way to prevent further conceptions. ${ }^{115}$

The clinic was shut down after ten days when a woman employed Comstockian tactics and posed as a poor mother of two with no way to support a third child. The woman requested information and devices, which she received and used to procure a warrant for the arrest of all three women for violating Section 1142 of the federal code. ${ }^{116}$ Police also arrested Sanger for violating section 1530 for “"maintaining a public nuisance"” after she reopened the clinic. ${ }^{117}$ Once again Sanger took her cause to the courts and this time she intended to take it to the Supreme Court, where she wanted to challenge the constitutionality of the law.

Before that happened New York state court indicted Ethel Byrne in January of 1917 and sentenced her to thirty days in a work-house. While Sanger awaited her own trial her sister went on a hunger and work strike until she was forcibly fed. Byrne's actions attracted national publicity to birth control and aroused public sentiment in favor of Byrne, until the governor of New York offered her a pardon if she promised not to disseminate birth control once released. Three weeks after Byrne's trial Sanger had her day in court and due to the publicity caused by Byrne's hunger strike Sanger's trial drew even more attention. ${ }^{118}$ Sanger refused to promise to obey the law if the court showed her leniency, she refused to cease

\footnotetext{
${ }^{115}$ Garrow, Liberty and Sexuality: The Right to Privacy and the Making of Roe V. Wade, 12.

${ }^{116}$ Sanger, My Fight for Birth Control, 158. "The Birth Control Clinic Cases," The Birth Control Review 1 (1917): 8 .

117 "The Birth Control Clinic Cases," 8.

${ }^{118}$ Sanger, My Fight for Birth Control, 170.
} 
providing birth control information to the women who begged her for information, and she refused to obey a law she believed harmed women. ${ }^{119}$

After Sanger served her thirty day sentence in a workhouse she appealed the case and in January 1918 a New York superior court judge ruled that a physician or someone acting on the physician's behalf could prescribe birth control to a married woman to prevent " "disease'." 20 Although this ruling did not give Sanger carte blanch to disseminate birth control, it reinterpreted section 1145 of New York state law that allowed physicians to provide contraception to prevent disease, which physicians interpreted as preventing only venereal disease. The judge ruled that the law was broad enough that it included disease as anything that caused illness and a physician or anyone acting on the physician's behalf could provide contraception in such cases. ${ }^{121}$ Sanger believed it was necessary to break the law to relieve the suffering caused by unwanted conception and for those willing to break the law to act as "beacon lights of human progress," but she accepted the ruling as a victory, albeit a small victory, and resolved not to violate the law anymore. ${ }^{122}$

Sanger developed the idea for a national campaign while she served her thirty day sentence and she believed that she better served the movement if she remained out of jail. She focused her attention on her "national campaign" of "agitation, education, organization, and legislation," which she aimed at the people she believed best able to change public opinion and the laws: wealthy and influential

\footnotetext{
${ }^{119}$ Ibid., 175.

${ }^{120}$ Garrow, Liberty and Sexuality: The Right to Privacy and the Making of Roe V. Wade, 13.

${ }^{121}$ Sanger, My Fight for Birth Control, 188.

${ }^{122}$ Margaret Sanger, "Shall We Break This Law?," The Birth Control Review 1 (1917): 4.
} 
women. ${ }^{123}$ She created a magazine that informed the public of the activities of the birth control movement as the first step to national education. Sanger, as managing editor, produced the first issue of The Birth Control Review in February 1917, which she "dedicated to the principles of intelligent and voluntary motherhood."

The Birth Control Review was less provocative than The Woman Rebel because it was not created to challenge the law and Sanger had no intention of providing contraceptive information within its pages. The magazine was an educational tool that featured articles about the progress of the movement, refuted popular arguments against birth control, and explained what birth control was. It also published letters from supporters or requests for information. The magazine also included information provided by the few birth control leagues in existence about their program.

The leagues that existed when the Review published its first issue differed from the leagues that formed throughout the 1920s and 1930s. These first leagues operated independently, most of them formed after Sanger's 1916 lecture tour or in response to arrests for disseminating information, and existed on both a state and city level. The early leagues provided birth control information to people who requested it and through such education hoped to effect the amendment of birth control laws. ${ }^{124}$

While Sanger initiated her national campaign the National Birth Control League continued its efforts to change legislation and in 1918 reported its progress to the Review, which Dennett helped publish as a member of the board of the New

\footnotetext{
${ }^{123}$ Sanger, My Fight for Birth Control, 190.

124 "What the Birth Control Leagues Are Doing," The Birth Control Review 1 (1917): 10-11.
} 
York Women's Publishing Company. ${ }^{125}$ During this time Dennett's involvement with birth control diminished after she founded the NBCL as she worked with peace organizations but, in 1918 she accepted the position of executive secretary and under her direction the NBCL redoubled its efforts to change birth control laws.

Dennett's tactics were similar to Sanger's because she believed that birth control had to become acceptable before laws could be changed. Like Sanger, Dennett initiated an education campaign not just about birth control but about the laws that prohibited birth control, distributed literature, and solicited support. The first NBCL sponsored bill went before the New York state legislature in 1917 and called for the removal of the phrase "preventing conception" in the laws. Although Dennett was not involved in the conception of this bill she supported it. But, after it failed to pass Dennett decided "the way in which sex itself was viewed" needed to change. ${ }^{126}$

Once Dennett believed the public had been sufficiently educated, she reintroduced a bill that removed any reference to "prevention of conception" in New York state law. She believed that people other than physicians such as nurses and social workers should be allowed to disseminate birth control. It was on this point that Sanger and Dennett disagreed because Sanger still supported doctors-only legislation even though she operated clinics and provided birth control herself. She believed only trained physicians should disseminate birth control based on her experiences in Holland and her belief that the diaphragm was the best birth control method, which required fitting on an individual basis best done by a physician.

\footnotetext{
${ }^{125}$ Chen, "The Sex Side of Life": Mary Ware Dennett's Pioneering Battle for Birth Control and Sex Education, 208.

${ }^{126}$ Ibid., 207.
} 
Nevertheless, Dennett was determined to introduce an open bill that removed any restrictions on disseminating contraception. Dennett, however, received little help from the NBCL because the organization was low on funds, which prompted Dennett to resign as executive secretary. Dennett formed another birth control organization, the Voluntary Parenthood League (VPL) in 1919, over which she had sole control. With the VPL Dennett changed the focus of her legislative campaign from changing individual state laws to altering the federal law. Changing the law on a state by state basis took longer than Dennett believed necessary when almost the same amount of effort expended could change federal law, which would then pave the way for legal birth control clinics. ${ }^{127}$

Sanger and Dennett both wanted all women to have access to birth control, but they disagreed on how that was achieved. Dennett believed that changing federal law had to happen first before anything else was done, but once it changed then every man and woman would have free access to birth control. Sanger's doctors-only approach, in Dennett's mind, helped only those who already had access to birth control, the wealthy, and not the poor who needed it the most. Dennett, however, refused to break the law while she challenged it.

When women wrote her asking for birth control information Dennett used it as an opportunity to educate more people about the laws that prevented the dissemination of such information, but she refused to provide the information. Dennett's solution was for women to speak to a physician about birth control, which contradicted her contention that it was the women who could not afford a private physician whom she most wanted to help. Although Sanger advocated doctors only

${ }^{127}$ Ibid., 212. 
legislation the unwillingness of most physicians to get involved and her desire to meet immediate birth control needs influenced her decision to provide that information even though she was not a physician. ${ }^{128}$ Sanger's beliefs and her actions contradicted each other, but combined they attracted the support of women from all classes and the medical profession because she gave women what she wanted and she also continued to advocate physician controlled dissemination. Dennett's unwillingness to compromise her "integrity" by breaking the law to provide contraception as well as her devotion to an open contraceptive bill alienated women and the medical profession, which allowed Sanger's new organization to become the primary birth control organization. ${ }^{129}$

\section{The American Birth Control League}

In November 1921 a new era of the birth control movement began at the first American birth control conference held in New York and organized by Sanger with the financial support of several wealthy and prominent women. One day prior to the conference, on November 10,1921, Sanger and the conference committee formed the American Birth Control League (ABCL) despite Sanger's misgivings about a controlling organization. The ABCL supplemented the efforts of individuals who fought for birth control and ensured that even as the individuals came and went the movement did not. The ABCL had similar goals as that of Dennett's organization because it wanted to affect public opinion, change federal laws, and educate, but the $\mathrm{ABCL}$ also employed field workers who worked with

\footnotetext{
${ }^{128}$ Himes, Medical History of Contraception, 316.

${ }^{129}$ Chen, "The Sex Side of Life": Mary Ware Dennett's Pioneering Battle for Birth Control and Sex Education, 215.
} 
states "where laws did not prevent clinics." population, food, and peace organizations because Sanger believed birth control, or rather the problem of too many children, was related to these issues. The ABCL also gave legitimacy to the planned conference.

The conference allowed Sanger and her colleagues to present their arguments for birth control, from medical to economic, to people from several states. The conference also gave opponents the opportunity to argue against birth control, which is why clergy were invited to the last meeting to discuss the question of morality and birth control. The debate never had time to begin, however, when Archbishop Patrick Hayes sent police to shut down the meeting about the morality of birth control because it was an "“immoral subject"."131 The incident brought national attention to an event that otherwise would have passed with only a mention of its occurrence. Archbishop Hayes' actions prompted critics to defend birth control against such a disregard for the "principle of freedom of speech.", ${ }^{132}$ Rather than prevent a birth control debate the archbishop created one that took place across the country in meeting halls and in newspapers. Newspapers and birth control supporters criticized the Catholic Church for its display of power over the police, which it should have had no control over, while birth control was made into a free speech issue that could be argued for without discussing the morality or immorality of the practice. Although the creation of the ABCL was overshadowed

\footnotetext{
${ }^{130}$ Sanger, Margaret Sanger: An Autobiography, 300.

${ }^{131}$ Ibid., 303.

${ }^{132}$ Sanger, My Fight for Birth Control, 220.
} 
by the fall-out from the archbishop's actions, its creation and the conference signified a turning point in the birth control movement. ${ }^{133}$

After the ABCL was incorporated in New York as a legitimate organization, Sanger was determined to open another birth control clinic operated by a physician in adherence to the law. The clinic would not only provide birth control to women that suited their individual needs, but would also allow Sanger to gather information about the types of women who sought birth control, which devices worked best, and which methods women preferred. In 1923 Sanger opened the Clinical Research Bureau (CRB) associated with but not funded by the ABCL. To fund the CRB Sanger received donations from a British manufacturer, the first but not the last time Sanger established a partnership with businessmen to secure the necessary resources for her activities. Sanger's collaborations with businessmen, physicians, scientists, and social workers, people who joined the ABCL board, allowed the $\mathrm{ABCL}$ to function, to grow, and to pursue its goals. These collaborations also altered the direction of the birth control movement to the dissatisfaction of Sanger. ${ }^{134}$

The ABCL board was content to settle into a routine of publishing educational materials, cooperating with state leagues, and increasing its membership while Sanger believed the League should use the increased favorable public opinion to its advantage. The League had substantial funds at its disposal by the end of the 1920s and Sanger believed it should use its secure public and financial position to mobilize a campaign that would finally change federal legislation. Like

\footnotetext{
${ }^{133}$ Ibid.

${ }^{134}$ Gordon, Woman's Body, Woman's Right: Birth Control in America, 246.
} 
Dennett, Sanger believed it was more efficient to challenge federal law rather than change the law state by state, but the ABCL refused to back such a campaign. Sanger resigned as president of the ABCL 12 June 1938 and devoted her attention to the $\mathrm{CRB} .^{135}$

While she disagreed with the ABCL's refusal to move in the direction she wanted, she had guided the nascent birth control movement with her goals of changing opinion, changing legislation, and giving women the means necessary to control their conception. When she disagreed with the direction the governing organization of that movement took, an organization of which she was president, she resigned. But, that organization did not fall apart without her leadership. She wanted it to be an organization that would continue to aid birth control supporters, regardless of who they were. At that, she succeeded. After her departure the ABCL continued. It affiliated with more state leagues, opened more clinics, and educated more people. It existed through a Depression and a world war to provide women with birth control. It changed its name and it adapted its goals but the organization Sanger helped found in 1921 never disappeared.

\footnotetext{
${ }^{135}$ In 1936 Sanger facilitated a judicial victory for birth control when the New York District Court ruled against the United States in United States v One Package of Japanese Pessaries. Dr. Hannah Stone, in her capacity as physician for the CRB ordered a new pessary for research purposes from a Japanese manufacturer. Dr. Stone violated Section 305 of the Tariff Act of 1930 which prevented the importation of any item from a foreign country that prevented conception. The New York District Court ruled that physicians could import items that prevented conception if they had a legitimate and legal purpose. The government appealed the ruling, but Judge Augustus Hand of the United States Circuit Court of Appeals upheld the New York District Court's decision. Although Judge Hand's decision did not repeal the Comstock law and did not apply to every state Sanger accepted the victory and dissolved the National Committee on Federal Legislation for Birth Control, which she had created to change federal legislation.
} 


\section{CHAPTER THREE: THE KENTUCKY BIRTH CONTROL LEAGUE}

There were a few who agreed wholeheartedly with the need for birth control, but no larger group or organization was willing to commit itself to any resolution favoring birth control. They said: 'The subject is much too controversial to risk. ${ }^{136}$

Under the direction of the American Birth Control League the birth control movement progressed throughout the 1920s, albeit slowly. By 1930 only fifteen states had leagues that operated clinics affiliated with the ABCL. The Great Depression awakened many Americans to the need for birth control, however. Birth control allowed the poor to get a "fair start and a fighting chance" if they were taught how use and had access to birth control. ${ }^{137}$ In 1933 Kentucky joined the birth control movement when the Kentucky Birth Control League formed to enact the goals of the ABCL in the state. The purpose of this chapter is to explain how the state birth control league developed and operated. It also demonstrates that the birth control movement progressed without Sanger as the leader of the dominant national birth control organization.

The Kentucky Birth Control League and its clinics would not have existed without the efforts of Jean Brandeis Tachau. The KBCL represented the constant efforts of the birth control movement to make birth control acceptable, and accessible, and to aid those who needed relief, especially the families who had too

\footnotetext{
${ }^{136}$ Elizabeth Cosby, "Family Planning in Kentucky: A History," (1973), 4.

${ }^{137}$ Just Looking On, "Birth Control," Courier Journal, 2 April 1931, 6.
} 
many children and no way to care for them. Tachau managed the KBCL and she spearheaded the efforts of the League within the state, but she also followed the program of action established by the ABCL for over a decade. Without the work done by the ABCL prior to 1933 and the aid provided by the ABCL after Tachau founded the KBCL, the League would not have reached as many people as it did. For fourteen years it adhered to a program of birth control dissemination and education, and even when the League was no longer needed as an organizational body the clinics created by it continued the work it had begun.

Jean Brandeis Tachau was born August, 221894 in Louisville, Kentucky the youngest of four daughters and the niece of Supreme Court Justice Louis Brandeis. She grew up in Louisville and spent most of her childhood at the family summer home, called Ladless Hill Farm on River Road, which had been built because of her "delicate" health as a child. ${ }^{138}$ Her family emigrated from Europe in 1848 and although they were of Jewish descent they did not join any Jewish communities in Louisville preferring, instead, to associate with other German and Austrian immigrants.

In 1911, after Tachau graduated high school, she continued her education at Bryn Mawr College, but chose not to return after one year. Between 1913 and 1915 she lived in Cambridge, Massachusetts with an uncle while she studied violin. When she returned to Louisville in 1915 she lived with her parents until, in 1921, she married Charles G. Tachau, a third cousin. Charles Tachau was willing, according

\footnotetext{
${ }^{138}$ Jean Brandeis Tachau, "Reminiscent Manuscript," (Louisville: University Archives and Records Center, 1970-1978), 4. Tachau does not explain the nature of her delicate condition, just that she was frequently in ill health as a child and remained so until 1929 when she had a "repair" operation as an adult.
} 
to Tachau, "to try anything and risk everything to cause improvement" either in business or society. ${ }^{139}$

Her parents influenced Tachau's own interest and willingness to effect improvement in society. The Brandeis family was wealthy and did not hesitate to use their wealth "for those causes which they deemed worthy." 140 Her father's "strong puritanical streak" and her mother's "strong sense of duty" instilled in Tachau a sense of obligation to do what she could to help the less fortunate. ${ }^{141}$ She acted on that sense of obligation when she overheard her parents discussing the need for a "juvenile court law" in 1908. After she heard the discussion she helped her mother send letters soliciting donations for the Legal Aid Society to help "ease the grinding miseries of the poor."142

Tachau continued her charitable work into adulthood and after World War I she worked with the newly created Red Cross Home Service aimed at providing for the social service needs of the families of men in the military. ${ }^{143}$ She received a few weeks training from social workers, but she said the training she received "was an eye-opener that lasted all my life" because she learned from the social workers "how to deal with a vast array of problems, mostly financial, but also including court processes, health services, etc." ${ }^{144}$

At that time Tachau also learned of a family for whom she believed "babies came too fast," which ignited her interest in birth control, a topic receiving national

\footnotetext{
${ }^{139}$ Ibid., 16.

${ }^{140}$ Ibid., 8.

${ }^{141}$ Ibid.

${ }^{142}$ Ibid., 35.

${ }^{143}$ Ibid.

${ }^{144}$ Ibid., 36.
} 
attention because of Margaret Sanger. ${ }^{145}$ Tachau, however, supported Dennett's Voluntary Parenthood movement in the early 1920s and with the aid of her father she worked to obtain local supporters for the movement. As chairman of the Council of Social Agencies, Tachau solicited support for Voluntary Parenthood with Dr. Morris Flexner's help. Dr. Flexner was the chairman of the Health Committee in Louisville whom Tachau met through her work with the Council of Social Agencies. While the nurses who worked with Dr. Flexner supported the idea, however the movement did not gain significant support in the community. ${ }^{146}$ Although Tachau failed to arouse enough support for the Voluntary Parenthood League, she continued to help mothers and children in the community. In the early 1930s Tachau worked with the Adoption Program for Babies and Small Children to address the needs of children. The Adoption Program later merged with the Children's Protective Association to become the Children's Agency. ${ }^{147}$ When she became president of the agency in 1932 she worked with other organizations, such as the Susan Speed Home, which helped unmarried mothers. Tachau's work bringing aid to mothers and children renewed her dedication to instituting an effective birth control movement in the community.

Tachau did not solicit support for birth control as she did for Voluntary Parenthood; rather Tachau, Dr. Alice Pickett and Mrs. Elise Ahrens organized an "informal committee" to discuss options and a possible course of action. ${ }^{148}$ By the early 1930s the effects of the Depression on the poor had already prompted

\footnotetext{
${ }^{145}$ Ibid., 37.

${ }^{146}$ Ibid., 38 .

${ }^{147}$ Ibid., 39.

${ }^{148}$ Ibid.
} 
members of the community to speak in favor of birth control based on the belief that if the poor had fewer children their economic suffering would be alleviated. The committee found that while no Kentucky state statute criminalized birth control information, federal law prevented shipping birth control devices or written information across state lines. Federal law, however, had not prevented other state birth control leagues from opening birth control clinics and working with cooperative physicians to meet birth control needs and by 1930 fifty-five clinics operated in fifteen states and twenty-three cities. ${ }^{149}$

In Kentucky the informal committee held a two-day meeting at which several people discussed birth control, including a woman from $\mathrm{ABCL}$ headquarters in New York from whom Tachau said she "learned a great deal," and Dr. Frederick Taussig who was a cousin of Tachau's mother. ${ }^{150}$ Within a few days the committee "decided to organize a Kentucky Birth Control League" and to open a clinic "as soon as possible." 151 This group elected Tachau the first president of the Kentucky Birth Control League, where she used the skills she learned from her social work training to bring in funding and support from the community. ${ }^{152}$ In 1933 the League received approval for a clinic in the outpatient department of the Norton Infirmary

\footnotetext{
${ }^{149}$ D'Emilio, Intimate Matters: A History of Sexuality in America, 244.

${ }^{150}$ Dr. Taussig conducted an abortion study in 1936 that family planners and birth control supporters used to support their argument that rather than cause abortions birth control prevented maternal deaths caused by abortions (Schoen, 161). Tachau, "Reminiscent Manuscript," 39.

${ }^{151}$ Ibid., 40.

${ }^{152}$ In addition to her work with birth control Tachau also devoted time to helping children and families that needed more than birth control provided. Throughout the 1930s Tachau also worked with Judge Lawrence Grauman, attorneys, and social workers on an adoption bill. She worked with Carita Ackerly and organized the Junior Job Service to help children find work to support their families, and as Chairman of Child Welfare Division of Health and Welfare Council she continued her efforts to change juvenile court laws.
} 
operated by Dr. Esther Wallner, who they hired because of the birth control training she received in Cincinnati. ${ }^{153}$

The May 1933 issue of the Birth Control Review listed the Kentucky Birth Control League for the first time as a state affiliate of the American Birth Control League along with groups from fourteen other states. The Review reported in the October 1933 issue the opening of the first Kentucky birth control clinic with Dr. Esther Wallner on staff as the physician and Lucille Rogers on staff as the social worker. The first clinic opened June 19,1933 and was open only to married white women who needed birth control for health reasons. The Norton Infirmary imposed the restrictions because the clinic operated from the Infirmary and was subject to the rules of the hospital. ${ }^{154}$

In the first year the clinic had a small budget and only saw eighty-seven patients, all of whom were referred by physicians or social agencies. But the longer the clinics operated, the more patients arrived by word of mouth or visited of their own volition. ${ }^{155}$ The number of patients remained small for only a brief period and increased due to the actions of the League. The League engaged in activities meant to attract patients, to educate the public, and to gain financial support. The League held annual meetings in Louisville to which the public was invited, sent field workers to other counties to discuss birth control interest with physicians and county health agencies, and provided birth control pamphlets to those who inquired.

\footnotetext{
${ }^{153}$ Tachau, "Reminiscent Manuscript," 41.

${ }^{154}$ Lucille Baker Hurt, "The Clients of the Planned Parenthood Clinic of Louisville, Kentucky," (Masters Thesis, University of Louisville, 1962), 6 .

${ }^{155}$ Ibid.
} 
The League also held membership campaigns each year to secure new members as the dues that funded the clinics. ${ }^{156}$

According to Tachau, it took a while before the clinic attracted patients and then the patients could only be married white women who needed birth control services for health reasons. ${ }^{157}$ Most often these women also had ill health because of "frequent child bearing or inadequate chance to recover from confinement." They wanted to practice family spacing and limitation because the number of children they had forced them to seek economic relief. By February 1936 the League reported to the ABCL that the number of patients doubled in 1935. The League also reported plans to open two more clinics with the aid of funding from the $\mathrm{ABCL} .{ }^{159}$

One of the new clinics opened at the Parish House at the Church of Our Merciful Savior to attend the birth control needs of African Americans. The League also opened clinics at the Cabbage Patch Settlement House and at Trinity Mission. By 1937 the League reported to the ABCL that it operated four clinics in Louisville. The League also wanted to extend its efforts outside Louisville. Between 1935 and 1936 the League sought to open clinics in Lexington, but encountered resistance because the people it approached there did not want to be under the leadership of Louisville. ${ }^{160}$

\footnotetext{
156 "News from the States," The Birth Control Review (1939): 208.

${ }^{157}$ Tachau, "Reminiscent Manuscript," 42.

${ }^{158}$ Kentucky Birth Control League, Questions and answers for solicitors, 24 March- 3 April 1939, Family Planning in Kentucky Collection, Special Collections, Kentucky History Center, Frankfort.

${ }^{159}$ The Birth Control Review (1936): 5.

${ }^{160}$ Tachau, "Reminiscent Manuscript," 42.
} 
By 1937 the League opened a clinic at 624 Floyd Street near the Children's hospital which became the primary clinic in Louisville. For a time operated in conjunction with the Norton Infirmary clinic. Then Mrs. Elsie Lang rented a house for the clinic and then it operated without the restrictions enforced upon them by the board of the Norton Infirmary. The Floyd Street clinic also accepted both white and African American patients though they were seen on different days and the African American clinic was operated by a separate "Negra physician."161

By 1937 the League had made significant progress throughout the state including opening several more clinics. ${ }^{162}$ The League worked with the Mountain Maternal Health League to provide for the birth control needs of people in Berea. The MMHL organized in 1936 to research different types of contraceptives that were more accessible to the women who lived in the mountain region of Kentucky. The MMHL wanted to use birth control to improve the health of mothers and children and in 1939 came under the direction of Dr. Louise Hutchins.

The KBCL hosted the national ABCL conference in Louisville in the spring of 1938 at which discussions were held about "the goal of birth control," the clinics, and birth control for "the negro family." "163 Tachau chaired a session about the use of birth control in public health programs and the president of the ABCL, Dr. Richard Pierson, chaired the Tuesday luncheon and its discussion on "Planned Parenthood." 164 While the conference gave representatives from state leagues the opportunity to discuss various issues, from the problems they had running clinics to

\footnotetext{
${ }^{161}$ Ibid.

162 "Progress in Birth Control Describe at League Meeting," Courier Journal, 27 October 1937, 6.

163 "The Southern Regional Conference," The Birth Control Review (1938): 83.

${ }^{164}$ Ibid.
} 
the future direction of the birth control movement, it also provided an educational opportunity to people not directly involved with the leagues. Members of the general public could attend any of the sessions held over the course of the two day conference. $^{165}$

Following the $\mathrm{ABCL}$ conference, the $\mathrm{KBCL}$ extended its education efforts in the state with the aid of Edna Rankin McKinnon of the Clinical Research Bureau. The ABCL sent McKinnon to Kentucky to promote the KBCL and, as Tachau said, the League "came alive under her stimulus."166 One of the first actions McKinnon took when she arrived in Kentucky was to visit Floyd and Pike counties with Tachau and Mary Helen Byck, where they met with physicians and mothers who had written the League for birth control advice. McKinnon "resolved on a program of state-wide education" because she found that mothers in the mountain region of Kentucky were desperate for a way to limit the number of children they had. ${ }^{167}$

After 1936, McKinnon decided to devote herself to educating women about birth control because she believed that by that point everyone who needed to be convinced about the necessity of birth control, from physicians to legislators, had been convinced. U.S. v One Package of Japanese Pessaries, December 7, 1936, removed the legal consequences that prevented many physicians from supporting birth control and paved the way for the 1937 decision by the American Medical Association, which had opposed reproductive control since the mid-nineteenth century, to accept birth control as a legitimate medical practice. ${ }^{168}$ The approval

\footnotetext{
165 "Birth Control League to Meet in Louisville," Courier Journal, 10 April 1938, 4.

${ }^{166}$ Tachau, "Reminiscent Manuscript," 42.

${ }^{167}$ Ibid.

168 "American Medicine Accepts Birth Control," The Birth Control Review 4 (1937): 1.
} 
came with qualifications, including the requirement that physicians control the dissemination of birth control through the clinics. But, by gaining the support of the professional medical community and a limited legal acceptance, the birth control the movement could focus on education and dissemination. McKinnon used the opportunity provided by these successes to teach women to use the tools necessary to controlling their family size. ${ }^{169}$

McKinnon spent three weeks traveling around Kentucky visiting physicians, women, and social workers to learn who was and was not open to learning about, using, and providing birth control. McKinnon found that out of fifty-nine physicians she questioned in six counties over ten days, fifty-five proved receptive to working with the League in providing birth control advice and devices to their patients, including four in Middlesboro who requested contraceptive powder. ${ }^{170}$ Tachau and McKinnon knew, however, that without an adequate source of funding it did not matter how many physicians were willing to work with the League and provide birth control if they did not have the resources to do so.

Private donations, membership dues, and limited financial support from the $\mathrm{ABCL}$ funded the $\mathrm{KBCL}$, but in its first year of operation it only had $\$ 627$ to finance the Norton clinic. Increased funding was necessary if the League wanted to extend its work in the state and reach the "indigent mothers" Tachau believed were a "constant drain on charity and tax funds." developed a campaign for funding in 1938 with the goal of procuring sufficient

\footnotetext{
169 "Birth Control Leader to Extend Work in State," Courier Journal, 6 June 1938, 6.

170 "Birth Control League Seeks Funds for Work," Courier Journal, 8 June 1938, 12. Edna Rankin McKinnon, Report of visits with doctors, 31 May 1938, Family Planning in Kentucky Collection, Special Collections, Kentucky History Center, Frankfort.

${ }^{171}$ Ibid.
} 
funds to provide birth control materials to every county in the state. Due to this funding drive the League developed a program that enabled representatives to visit county seats and work with willing physicians.

Not every physician was willing to work with the League; McKinnon encountered one African American physician in Middlesboro who wanted to discourage African Americans from limiting the number of children they had, most physicians were open to providing patients with birth control. ${ }^{172}$ So the League hired Mrs. George Cohn Sr. as a field representative who was responsible for meeting with physicians and providing them with birth control supplies as they needed them. Mrs. Cohn met with doctors to "encourage their cooperation, and bring contraceptive supplies." ${ }^{, 173}$ Tachau kept a record of these visits over the course of six years from 1938 to 1944 and they show that in many cases even if a physician was not personally willing to provide birth control he was willing to refer a patient to a physician who could meet their needs.

Physicians from counties in every part of Kentucky cooperated with the League because they agreed with the League that birth control was a necessity. Even physicians like Dr. Skaggs of the Anderson County Health Office, said that while he did not want birth control material he would refer patients who inquired about birth control to Dr. Caudill. The League provided these physicians with birth control materials from powders and jellies to educational pamphlets most often provided by the $A B C L$.

\footnotetext{
${ }^{172}$ Edna Rankin McKinnon, 31 May 1938.

${ }^{173}$ Tachau, "Reminiscent Manuscript," 43.
} 
Education constituted a constant component of the ABCL and KBCL's programs, whether it was educating people about how to use birth control, the necessity of birth control, or the differences between birth control and abortion. While McKinnon was still in Kentucky she and Tachau gave a series of question and answer interviews on WHAS radio in June 1938 so that the public would be aware of the progress the League had made in gaining the support of physicians. ${ }^{174}$ McKinnon also explained that while she had found a willingness by physicians to supply birth control she found that the general public was in desperate need of education. They needed to be aware that birth control enabled them to have smaller families so the economic problems of the Depression could be relieved, and they needed to know that by using birth control they were not just helping themselves but rather they helped the entire community. ${ }^{175}$

Despite McKinnon and Tachau's efforts, the criticism the birth control movement and the $\mathrm{KBCL}$ received from local Catholics and the Jefferson County Grand Jury due to an ad the Courier Journal demonstrated that further education was necessary. Between 1933 and 1941 over thirty articles and letters had appeared in the Courier Journal that reported on the activities of the KBCL or expressed a, more often than not, favorable opinion of birth control. The Courier Journal had published these articles without drawing criticism or opposition from readers.

Then, on Easter Sunday, April 1941, the Courier Journal published an advertisement sponsored by the National Committee for Planned Parenthood detailing the problems the children born in 1941 would face fifteen years later.

\footnotetext{
${ }^{174}$ Edna Rankin McKinnon and Jean Brandeis Tachau, WHAS interviews, 13-17 June 1938, Family Planning in Kentucky Collection, Special Collections, Kentucky History Center, Frankfort.

${ }^{175}$ McKinnon and Tachau, WHAS interviews, 17 June 1938.
} 
According to the Committee only sixty-three of 100 would be healthy, but the number would be much higher if the people who needed birth control the most, the people who made less than $\$ 1000$ a year, had access to the necessary information. ${ }^{176}$ The ad was meant to educate the public about Planned Parenthood by giving them the opportunity to request more information. The ad also solicited donations that could either be sent to the Committee or to the Louisville Maternal Health Clinic.

The Planned Parenthood advertisement drew harsh criticism from readers within five days. One reader believed such an advertisement caused "division and disunity" because it advocated the "disintegration and decay" of the family at a time when it was needed most. ${ }^{177}$ It was evident in many of the responses to the ad that the advent of war had a significant negative impact. One reader argued that such an ad advocated a reduction in the resources most necessary to ensuring the security of the country against attack. ${ }^{178}$ Birth control threatened the birth rate at a time when Americans were concerned about the loss of life and manpower should America enter the war.

Other readers opposed birth control on moral and religious grounds, including Archbishop John Floersh who composed a letter read in every Catholic parish in Louisville. Floersh made note of the prior attention birth control received in the paper and stated that the advertisement represented the "climax" of such "favorable publicity" because it did not just report the activities of the KBCL but encouraged people to support birth control financially and morally. ${ }^{179}$ The harshest

\footnotetext{
176 "National Committee on Planned Parenthood," Courier Journal, 13 April 1941, 12.

${ }^{177}$ Rev. Chas C. Boldrick, "No Need of Setting Guards," Courier Journal, 18 April 1941, 8.

178 Julia Fleece, "Birth Control and Manpower," Courier Journal, 23 April 1941, 8.

179 "Ad Protested by Floersh," The Louisville Times, April 21 1941, 1.
} 
critics claimed birth control was nothing more than murder of the unborn.

Although Tachau did not respond to Floersh's moral critique, she did respond when the Jefferson County Grand Jury condemned the ad and the Courier Journal for issuing an "invitation to abortion." 180

The Grand Jury accused the Planned Parenthood Committee of promoting abortion, an illegal activity in Kentucky. If the Grand Jury convinced a judge that birth control was an "invitation to abortion" then the KBCL and its clinics faced legal consequences. ${ }^{181}$ Tachau, therefore, undertook the task of educating the Grand Jury foreman about birth control as a preventative of abortion not an invitation to it by engaging in activities used for years by her and sanctioned by the national birth control organization.

Tachau did not criticize the Grand Jury or the Catholic community but instead responded to their accusations that birth control was murder. Tachau reiterated the statement in the Planned Parenthood ad that birth control did not lead to abortion it prevented the "last desperate act of a mother who has failed to receive birth control advice." 182 One of the primary goals of the birth control movement was to "check the common practice of inducing abortions by extending that of preventing conceptions." 183 If mothers had access to birth control then mothers would have no need to obtain an abortion and engage in such an illegal activity. Birth control advocates used this argument often when they encountered opposition that equated birth control to abortion.

\footnotetext{
180 "Grand Jury Upbraids C.-J. For Ad on Birth Control," Courier Journal, 24 April 1941, 1. ${ }^{181}$ Ibid., 9.

${ }^{182}$ Kentucky Birth Control League, Questions and answers for solicitors, 24 March- 3 April 1939, Family Planning in Kentucky Collection, Special Collections, Kentucky History Center, Frankfort. ${ }^{183}$ Ibid.
} 
According to a set of questions and answers created by the KBCL for the general public given to solicitors the KBCL stated that only more birth control clinics would prevent the almost 700,000 abortions and subsequent 10,000 mother deaths that occurred each year. ${ }^{184}$ Sometimes the argument was successful as in the case of Dr. Overall who had been interviewed by a KBCL field worker in March 1941. Dr. Overall initially expressed the opinion that birth control was "murder" but the field worker wondered if he did not mean abortion. ${ }^{185}$ Although the worker did not elaborate on what she did to convince Dr. Overall of the difference between abortion and birth control she did mention that he later expressed sympathy and the belief that something needed to be done for the women. ${ }^{186}$

Tachau's success with the Grand Jury members is unknown, but that she made a concerted effort to educate them is not. The accusations caused by the ad demonstrated that, as stated by Allison Moore in 1937, the task of educating the public remained the purview of the leagues and was an ongoing struggle. In addition to explaining the position that birth control prevented abortions she also sent just the foreman an educational pamphlet. ${ }^{187}$ As Tachau explained she and the KBCL did not wish to impose their beliefs on others, but they wanted the ability to solicit the support of like-minded individuals. She believed the condemnation by the Grand Jury was the result of ignorance of the purpose of the KBCL and the birth

\footnotetext{
${ }^{184}$ Ibid.

${ }^{185}$ Report of visits to doctors, 3 March 1941, Family Planning in Kentucky Collection. ${ }^{186}$ Ibid.

${ }^{187}$ Pamphlets had been a popular method of educating the American public about birth control since the nineteenth century, a tradition continued by Sanger and Dennett, and although Tachau did not write her own pamphlet the KBCL often sent birth control pamphlets provided by the ABCL. Such pamphlets were most often sent to people who requested the information, the KBCL received numerous letters from interested physicians, desperate mothers, and individuals who wanted to distribute the information to their communities.
} 
control movement, which threatened the ability to educate and obtain the support of those who agreed with the KBCL. ${ }^{188}$

By 1941 birth control received medical and legal acceptance, which allowed the state leagues to work with physicians to provide birth control, but as the chairman of the ABCL board said in 1937 the movement faced "formidable hurdles." 189 The movement faced opposition with significant political power, including the Catholic Church, which could hinder the efforts of the leagues to provide birth control to those who needed it. When Archbishop Floersh condemned the Planned Parenthood advertisement as promoting murder and drew the support of not only other Catholics but the Jefferson County Grand Jury, he demonstrated the power the Catholic Church wielded over the public. The KBCL had operated clinics in Louisville since 1933 when it was still illegal to dispense contraceptive information without significant opposition even from the Catholic Church, but when Floersh spoke out he influenced a legal body that could hinder the KBCL's efforts. While Floersh condemned the ad and birth control on moral grounds the Grand Jury condemned it on legal grounds.

The KBCL remained active after the events of April 1941 as did the clinics, but the state of organized birth control in Kentucky had already started to change even before the ad appeared. By 1938 the KBCL's program had expanded so much that a new group formed to operate just the Louisville clinics so the KBCL could focus on other activities. ${ }^{190}$ The League made significant progress in 1938 and

\footnotetext{
${ }^{188}$ Jean Brandeis Tachau, Letter to the editor of the Courier Journal, 24 April 1941, Family Planning in Kentucky Collection.

189 "American Medicine Accepts Birth Control," 2.

${ }^{190}$ Hurt, "The Clients of the Planned Parenthood Clinic of Louisville, Kentucky," 6.
} 
created programs in twelve counties and hired Louise Bowser who managed both the clinic and field work. ${ }^{191}$ The Louisville Maternal Health Clinic formed and operated the clinics in Louisville, but consolidated into one clinic at the 624 Floyd Street location which served the entire city until 1960.

When the Birth Control Federation of America, formerly the ABCL, changed its name to the Planned Parenthood Federation of America in 1942, the LMHC changed the name of the Louisville clinic to the Louisville Planned Parenthood Clinic in 1943 to reflect the new direction of the movement from a focus on family limitation to child spacing, which was a more palatable objective "endorsed my men.", 192 Although the BCFA did not change its name until 1942 it already included planned parenthood and child spacing language in its program, as demonstrated by the National Committee for Planned Parenthood advertisement. Planned Parenthood remained a birth control organization and continued efforts to educate and provide birth control to the public. It also expanded its program to include other aspects of reproduction. The Louisville Planned Parenthood reflected the changing nature of the national birth control organization when the Louisville clinic included a "fertility referral service" in its program in $1947 .{ }^{193}$

The war affected operation of the Louisville clinic because the number of available physicians decreased, but the League and the clinic remained active in the state until 1947. By 1947 interest in the birth control movement had decreased enough that a state league was no longer warranted and the KBCL disbanded after

\footnotetext{
191 "News from the States," The Birth Control Review (1938): 144.

${ }^{192}$ Referendum to change name of state leagues, 17 April 1941, Family Planning in Kentucky Collection, Kentucky History Center, Frankfort.

${ }^{193}$ Hurt, "The Clients of the Planned Parenthood Clinic of Louisville, Kentucky," 8.
} 
fourteen years of operation. In those fourteen years, the League operated clinics, including one that served the African American population. With the help of the $\mathrm{ABCL}$ and its representatives the League was able to serve almost every county in the state by working with local physicians, health offices, and community leaders to distribute birth control information. In addition, the League did its part to educate the public about the benefits of birth control, and provided a much desired service, for which it received significant support even when faced with powerful opposition. Tachau and the KBCL received numerous letters of thanks from women who professed that birth control allowed them to enjoy their children more. Most importantly, the work of the League lasted even after the League itself no longer existed.

The Louisville Planned Parenthood Clinic provided family planning services to the community that included marriage and pre-marital counseling in addition to providing birth control and fertility information. Tachau believed educating people not just about birth control but about marriage and families was a way to "spread the word of Planned Parenthood among young people before it was too late."194 Tachau's belief in a comprehensive education plan imitated the increased scope of the PPFA. Jean Brandeis Tachau was the first and only president of the KBCL, but when it disbanded she continued to work with the Louisville Planned Parenthood Clinic as its Executive Secretary, a position she occupied as late as 1962. For over seventy years Louisville has not been without a clinic that provided inexpensive and accessible birth control due to the work of Jean Brandeis Tachau, her colleagues, the KBCL, and the national birth control organization, whatever its name.

\footnotetext{
${ }^{194}$ Tachau, "Reminiscent Manuscript," 43.
} 


\section{CONCLUSION: PLANNED PARENTHOOD AND THE BIRTH CONTROL PILL}

[T] he acceptance of family planning as an essential element of responsible parenthood, stable family life and social harmony-through education for family planning, the provision of necessary services, and the formation of research in the field of human reproduction. ${ }^{195}$

In 1942, the Birth Control Federation of America (BCFA), formerly the $\mathrm{ABCL}$, changed its name to the Planned Parenthood Federation of America (PPFA). The name change reflected the new direction of the national birth control movement. Planned Parenthood focused less on changing legislation and education and more on increasing its services as well as becoming a more mainstream social organization. Previous victories by the birth control movement including increased public acceptance allowed Planned Parenthood to focus on developing a program of family planning and creating better birth control methods. This chapter examines the relationship between Planned Parenthood and population control and its effect on the development of the oral contraceptive.

Although the public accepted birth control more than it had before the Depression era, birth control still had negative connotations for many Americans, including an association with negative eugenics. As physicians and eugenicists

\footnotetext{
${ }^{195}$ Hurt, "The Clients of the Planned Parenthood Clinic of Louisville, Kentucky," 9.
} 
worked with the birth control movement in the 1930s and 1940s they advocated phrases such as child spacing or family planning that indicated a more positive aspect of birth control. Birth control supporters had used these phrases before, Sanger had become aware of birth control as a tool for child spacing while in Holland, but they never replaced birth control as the name of the movement. By 1941 leaders in the birth control movement developed another phrase to represent the birth control movement and in 1942 Planned Parenthood replaced birth control as the name of the movement. ${ }^{196}$

Leaders in the birth control movement chose the name to put a more positive spin on birth control, but it also represented the birth control movement's desired role as a social organization. Planned Parenthood still operated birth control clinics, educated men and women about birth control, and supported less restrictive birth control policies, but it also increased the services it provided. ${ }^{197}$ Rather than focus on the woman and her right to control her reproduction, Planned Parenthood focused on the entire family and thus society. Even before the name changed Sanger and others argued that birth control was a tool that improved society's condition, but the PPFA's programs demonstrated a dedication to improving society that the BCFA's had not.

By the late 1940s and early 1950s the PPFA's dedication to improving the family and society through family planning and responsible parenthood contributed to a relationship between family planning and population control. During the Depression and World War II opponents criticized birth control for causing

\footnotetext{
${ }^{196}$ Gordon, The Moral Property of Women: A History of Birth Control Politics in America, 244.

${ }^{197}$ Planned Parenthood clinics still provided women with contraception, but they also attended to other aspects of women's reproductive health that did not include providing contraception.
} 
depopulation. For some people birth control meant fewer consumers, consumers needed to aid the economic recovery of the nation and when the war began those consumers became potential resources in the war effort. ${ }^{198}$ Even earlier than the Depression and the war fears of under population among the fit in society, wealthy and educated "Yankee" population, contributed to opposition of birth control. After the war, however, the awareness of a growth in the "world population," an awareness achieved through the overpopulation research of organizations such as the Milbank Memorial Fund, increased fears of overpopulation. ${ }^{199}$

Birth control provided a tool necessary to controlling overpopulation, which the United States recognized as a major threat to the development of third world countries. If birth rates declined in third world countries, then their economies could develop which in turn contributed to a better world economy. When the United States government included population control in its foreign policy, Planned Parenthood's position increased in the United States and the world. The recognition of Planned Parenthood's role in efforts to curb overpopulation provided the organization with support that allowed it to increase its family planning programs and facilitated the development of the oral contraceptive. Throughout the 1950s and 1960s population control influenced Planned Parenthood's policies and programs. While the International Planned Parenthood Federation organized population control efforts on an international scale the PPFA created Planned Parenthood-World Population (PP-WP) to direct efforts in America. Like its

\footnotetext{
${ }^{198}$ Kennedy, Birth Control in America: The Career of Margaret Sanger, 236. Thomas P. McGovern, "Birth Control and Manpower," Courier Journal, 23 April 1941, 8.

${ }^{199}$ Gordon, The Moral Property of Women: A History of Birth Control Politics in America, 280.
} 
predecessors one of PP-WP's objectives was the education of Americans about the dangers of overpopulation with birth control as the means to solving the problem. ${ }^{200}$

Planned Parenthood did not abandon its other objectives of providing family planning services, improving the reproductive health of women, or researching better contraceptive methods, but population control dominated its activities throughout the 1950 s and 1960s. Even the most significant contraceptive development of the 1950 s, the oral contraceptive, was inspired by a desire to create better methods to control the population. Like so many of the accomplishments of the birth control movement, Sanger's influence contributed to the development of the oral contraceptive.

She spent the first several years of her birth control career seeking out better methods and when she found the diaphragm, even though it was not a new method, she spent many more years making sure women had access to it because she believed it was the most reliable method. Until the 1950 s no new method of contraception was developed, although in the early twentieth century physicians such as Ernst Gräfenberg experimented with updated versions of intrauterine devices (IUD), which had also existed for years. The IUD failed to gain popularity as a contraceptive device throughout the 1930 s and 1940 s even though the IUD created some of the "lowest pregnancy rates ever achieved by a contraceptive."201 The side effects and problems caused by these early twentieth century IUDs made from "silk gut and silver wire," however, outweighed the benefits because women often experienced inflammation and excessive bleeding and cramping during the

\footnotetext{
${ }^{200}$ Ibid., 282.

${ }^{201}$ James Reed, From Private Vice to Public Virtue: The Birth Control Movement and American Society since 1830 (New York: Basic Books, Inc., Publishers, 1978), 276.
} 
menstrual period. ${ }^{202}$ By the 1920s some physicians used updated IUDs made out of silk sutures but these IUDs still required careful supervision by a physician to prevent problems.

By the late 1940 s, although the diaphragm and IUD created low pregnancy rates, Sanger had become convinced they were not effective enough to solve the population problem. Sanger had ideas about new methods, but she needed a physician willing to do the research and she needed funding for any research, both of which she obtained by 1952 . The physician was Dr. Gregory Pincus and the financial benefactor was Katharine Dexter McCormick. McCormick was an MIT educated heiress who dedicated her life to various women's rights causes. She first met Sanger in 1917, but her involvement with the birth control movement began in 1921. McCormick donated her time and money to the birth control movement because she believed birth control was an "“instrument of liberation'."203 Even when she disagreed with the direction of the movement after it became Planned Parenthood she donated money to the PPFA for research and organizing purposes.

McCormick never donated more than $\$ 5,000$ to the PPFA until 1953 when she donated $\$ 20,000$ to fund Dr. Pincus' oral contraceptive research. McCormick's donations to pill research totaled $\$ 2$ million. Dr. Pincus received PPFA funding for research between 1948 and 1949, but that research failed to deliver significant results for contraception. Between 1951 and 1952, however, he received more PPFA funding and studied hormonal contraceptive possibilities. The results of that study, the successful use of progesterone to prevent ovulation in rats, convinced the PPFA

\footnotetext{
202 Ibid., 275.

${ }^{203}$ Fields, Katharine Dexter Mccormick: Pioneer for Women's Rights, 180.
} 
to give Dr. Pincus a grant to further develop the hormonal contraceptive and enter clinical trials. ${ }^{204}$ The money for this grant came from McCormick who met with Dr. Pincus and his colleagues in 1953 at which point she gave him $\$ 20,000$.

With the aid of McCormick's money Dr. Pincus and his colleagues, Dr.

Chang Min-Chueh and Dr. John Rock, experimented until they discovered that the most favorable and reliable combination of hormones was that of Enovid, a progestin, combined with a small amount of estrogen. ${ }^{205}$ Dr. Rock first tested the oral contraceptive on "a limited number of highly motivated patients" who came to the Worcester lab where the physicians did most of their research. ${ }^{206}$ Pincus reported the successful outcome of those tests, the effectiveness of the pill at preventing ovulation, but expressed a desire to test the progesterone contraceptive on a larger group of women.

Pincus and his colleagues; therefore, took their pill to the women of Puerto Rico. Because Puerto Rico was a poor and underdeveloped country due to overpopulation it provided a suitable test case not only to show the effectiveness of the pill as a contraceptive but as a tool that curbed overpopulation. In 1956, the physician who carried out the trials for Pincus reported a favorable success rate for the 221 women who used the Enovid pill although seventeen percent reported side effects including break-through bleeding. Pincus, however, discovered that if the

\footnotetext{
${ }^{204}$ Ibid., 256.

${ }^{205}$ Himes, Medical History of Contraception, xxviii.

${ }^{206}$ Gordon, The Moral Property of Women: A History of Birth Control Politics in America, 287.
} 
women who reported side effects took antacids with Enovid the side effects diminished. $^{207}$

In 1957 the Food and Drug Administration (FDA) approved Enovid, but not for use as a contraceptive. Physicians used Enovid to treat women with menstrual or infertility problems. G. D. Searle, the company that produced Enovid, did not submit an application to the FDA for Enovid's approval as a contraceptive until 1959. The FDA hesitated to approve Enovid for contraceptive use because the potential side effects of the long term use of Enovid by healthy women were unknown. After the FDA delayed the decision making process twice Dr. Rock requested hearing at which the FDA appointed physician, Dr. Pasquale DeFelice, requested further lab tests from Searle.

The lab tests supported the data Dr. Rock provided that displayed no link between use of the pill and blood clots. Although Dr. DeFelice expressed a moral and religious objection to Enovid the pill passed FDA drug safety requirements, proved more effective than other contraceptive methods, and the FDA approved Enovid for contraceptive use on May $10,1960 .^{208}$ The pill was not consequence free because it had to be taken at a specific time every day for it to be effective, it was also expensive, and it caused nausea and irregular bleeding. ${ }^{209}$ Yet, the benefits of the pill outweighed the shortcomings, however, and McCormick, Sanger, and birth control supporters celebrated the approval of the pill.

\footnotetext{
${ }^{207}$ Reed, From Private Vice to Public Virtue: The Birth Control Movement and American Society since 1830, 361.

208 "U.S. Approves Pill for Birth Control," New York Times 1960, 75.

${ }^{209}$ Himes, Medical History of Contraception, xxviii.
} 
The pill changed contraception and represented the pinnacle of Sanger's life's work. Unlike the diaphragm, the pill proved easy to use and unlike the condom it gave women more control over their contraception; thereby meeting a goal of birth control advocates since nineteenth century women initiated the voluntary motherhood movement. The pill meant twentieth century women did not have to rely on abstinence, their husbands, or ineffective devices for their contraception-objectives of Sanger's since she started her fight for birth control. The pill did not change public opinion about sex and contraception; rather, it was an indication of how much the birth control movement had achieved since its inception in the early twentieth century.

The federal government's acceptance manifested in its use of the pill as a tool in the "War on Poverty." 110 Thirty years after Sanger argued before Congress that birth control relieved poverty the United States government included funding for family planning programs in its welfare budget. For many women, however, the pill was a "tool for autonomy;" a tool Planned Parenthood clinics provided. Within three months of the FDA's approval Planned Parenthood permitted dissemination of the Pill through its affiliated clinics. Despite the expense of the pill, about $\$ 10$ a month, the number of patients at Planned Parenthood clinics increased and Searle's Enovid profits increased from $\$ 20$ million to $\$ 40$ million over two years so that the pill was the most popular contraceptive on the market. ${ }^{211}$ Approval and the popularity of the Pill signified the public's acceptance of non-procreative sex, of the

\footnotetext{
${ }^{210}$ Gordon, The Moral Property of Women: A History of Birth Control Politics in America, 288 and 289.

${ }^{211}$ Tachau, "Reminiscent Manuscript," 45. Reed, From Private Vice to Public Virtue: The Birth Control Movement and American Society since 1830, 364.
} 
need for population control, and of the right of women to control their reproduction.

By 1965 physicians and birth control clinics in every state provided birth control to their patients without restrictions after the United States Supreme Court decision in Griswold v Connecticut removed the last state anti-contraception law. The Connecticut Birth Control League (CBCL) first challenged Connecticut's birth control legislation in the court after police closed the Waterbury birth control clinic. In 1940 the Connecticut Supreme Court upheld an 1879 state law that prohibited even physicians from providing birth control. For the next twenty-five years the CBCL and later Connecticut Planned Parenthood engaged in legislative and judicial campaigns with little success until 1965. Like Sanger who defied New York State law when she opened the Brownsville clinic Estelle Griswold, the executive director of Connecticut Planned Parenthood, opened a clinic in New Haven in 1961 because she wanted police to close it. In November 1961, New Haven police complied when they closed the clinic and arrested Griswold as well as physician Lee Buxton. ${ }^{212}$ Griswold, like Sanger intended when police arrested her for opening the Brownsville clinic, wanted to take her case before the United States Supreme Court, but unlike Sanger Griswold succeeded. Griswold's attorney, Katie Roraback, challenged the constitutionality of the 1879 statute on the grounds that it violated the freedom of speech and an alleged right to privacy that Roraback argued was inherent to the Fourth, Fifth, and Third Amendments. Once Connecticut found Griswold and Buxton guilty, Roraback filed an appeal for review by the Connecticut Supreme Court in 1963. By the spring of 1964 the Connecticut

\footnotetext{
${ }^{212}$ Garrow, Liberty and Sexuality: The Right to Privacy and the Making of Roe V. Wade, 201.
} 
Supreme Court of Errors confirmed the convictions of Griswold and Buxton and by September their lawyer filed an appeal with the United States Supreme Court. Both sides argued their case in March 1965 and the Supreme Court handed down its decision on June 7, 1965. Seven justices agreed that the Connecticut statute violated the right of privacy of married couples. ${ }^{213}$ Among the dissenting justices Hugo Black and Potter Stewart found the Connecticut statute "offensive" but not unconstitutional because the right to privacy did not exist in the constitution. ${ }^{214}$

Through the actions of many individuals, over the course of sixty years, the birth control movement accomplished its objectives. The men and women who worked with the ABCL, BCFA, and PPFA changed public opinion so much that in 1966 former President Dwight D. Eisenhower expressed his belief that "birth control information should be made easily accessible 'so that every family may decide for itself, wisely and freely, the course it chooses to take'."215 Five years after Griswold the movement's legislative efforts succeeded when Congress removed the prohibition against contraceptive information and devices from the Comstock law. Further success occurred on March 22, 1972 when the United States Supreme Court decided in Eisenstadt v. Baird that a woman's marital status had no bearing on her right to obtain birth control from a physician; every woman who wanted and needed to control her reproduction had the legal right to do so.

The birth control movement was, at times, a feminist movement and/or a social movement depending on the political and economic environment. The movement began as a feminist movement during the early twentieth century when

\footnotetext{
${ }^{213}$ Ibid., 247.

${ }^{214}$ Griswold V. Connecticut, (1965).

215 "Eisenhower Urges Birth Control Data Be Available to All," New York Times, November 29 1966, 30.
} 
women organized and agitated for their personal and individual autonomy rights. Sanger believed birth control was one more aspect of those rights; the instrument that would raise women from their inferior status. ${ }^{216}$ When leaders in the movement realized that birth control received more support if it argued that birth control improved families the movement changed its name to Planned Parenthood. When the federal government's concern about overpopulation increased the movement emphasized the use of birth control as a tool that curbed population growth. The movement's ability to adapt fostered its longevity, but even as it changed it never ceased its focus on providing women with effective birth control methods that controlled their reproduction. For over eighty years a birth control organization has supported birth control education and dissemination and in its capacity as Planned Parenthood it continues to operate clinics, educate the public, and encourage scientific research.

${ }^{216}$ Margaret Sanger, Woman and the New Race (New York: Brentano's Publishers, 1920), 2. 


\section{REFERENCES}

Because the focus of this thesis is on the individuals and the ways they educated the public about birth control certain primary sources were valuable. One important source is The Birth Control Review, which was produced as the voice of the movement from 1917 until 1940. Margaret Sanger served as the original editor and she dedicated the paper to the principles of voluntary motherhood. The Review provided a medium for birth control advocates, including Mary Ware Dennett, Dr. Hannah Stone, and, as mentioned, Norman Himes, to make their arguments to the public as to why they supported birth control. The Review also featured information about the latest developments in the movement, discussed the advancements state leagues made, and advertised educational books and pamphlets.

The chapter about the Kentucky Birth Control League is based on the papers Jean Brandeis Tachau maintained as president of the League including details of her field work, newspaper clippings, and transcripts of radio interviews intended to educate the public. The field work records describe the work done in various Kentucky counties from 1938 to 1944 . Field workers visited physicians and determined which physicians would distribute birth control information and devices. Tachau also kept records of letters the League received from individuals interested in birth control literature because they wanted to control their conception or letters from people who wanted to distribute information among the women in their communities. The League records illustrate the actions taken by Tachau and 
her colleagues to disseminate birth control information throughout the state.

\section{News papers}

Courier Journal (Louisville). 8, 12, 27 February 1928-13, 15 March 1928.

Courier Journal (Louisville). 4, 24 March 1930.

Courier Journal (Louisville). 2, 7, 10 April 1931.

Courier Journal (Louisville). 26 February 1933; 3 April 1933; 21, 26 October 1933.

Courier Journal (Louisville). 18, 22 March 1934; 15 April 1934; 1, 14, 17 May 1934; 24 October 1934.

Courier Journal (Louisville). 28 October 1936.

Courier Journal (Louisville). 11 April 1937-22, 27 October 1937.

Courier Journal (Louisville). 10, 24 April 1938; 6, 8 June 1938; 25 October 1938

Courier Journal (Louisville). 19, 24, 25, 31 March 1939.

Courier Journal (Louisville). 23 January 1940; 7 February 1940; 14, 24 March 1940; 12 April 1940.

Courier Journal (Louisville). 13, 18, 21, 23, 24 April 1941; 27 May 1941; 19 September 1941

Courier Journal (Louisville). 18 February 1942.

Courier Journal (Louisville). 6 December 1959.

Courier Journal (Louisville). 29 September 1967.

The Louisville Times (Louisville). 21 April 1941.

New York Times (New York). 4 August1960.

New York Times (New York). 15 October 1963.

New York Times (New York). 10 September 1966-29 November 1966.

\section{Archival Materials}

Family Planning in Kentucky Collection, 1938-1987, 2000M02, Special Collections, 
Kentucky History Center, Frankfort.

Tachau, Jean Brandeis. "Reminiscent Manuscript." Louisville: University Archives and Records Center, 1970-1978.

\section{Published Materials}

Beebe, Gilbert Wheeler, Ph.D. Contraception and Fertility in the Southern Appalachians. Baltimore: The Williams \& Wilkins Company, 1942.

Dennett, Mary Ware. Birth Control Laws: Shall We Keep Them, Change Them, or Abolish Them. New York: The Grafton Press, 1926.

The Sex Side of Life: An Explanation for Young People: Mary Ware Dennett, 1928.

Goldstein, David, LL.D. Suicide Bent: Sangerizing Mankind. St. Paul: Radio Replies Press, 1945.

Himes, Norman. Medical History of Contraception. New York: Gamut Press, 1963.

Mosher, Clelia Duel. Health and the Woman Movement. Second ed. New York: The Womans Press, 1918.

Sanger, Margaret. Family Limitation. New York, 1914.

_. "Humble Pie." The Woman Rebel, April 1914.

_. Margaret Sanger: An Autobiography. New York: W.W. Norton \& Co., 1938.

- My Fight for Birth Control. New York: Maxwell Reprint Company, 1931.

-Woman and the New Race. New York: Brentano's Publishers, 1920.

Wright, Henry Clarke. The Unwelcome Child or, the Crime of an Undesigned and Undesired Maternity. Boston: B. Marsh, 1858.

\section{Journal Articles}

"Affiliated State Organizations." The Birth Control Review 17 (1933).

"American Medicine Accepts Birth Control." The Birth Control Review 4 (1937).

Benjamin, Hazel. "Lobbying for Birth Control." The Public Opinion Quarterly 2 (1938). 
"The Birth Control Clinic Cases." The Birth Control Review 1 (1917).

Buckman, Rilma. "Social Engineering: A Study of the Birth Control Movement." Social Forces 22 (1944).

Greenhill, J.P. "Medical History of Contraception." The Journal of Political Economy 45 (1937): 2.

Himes, Norman. "Next Steps in the Movement." Birth Control Review (1929).

Sanger, Margaret, Frederick Blossom, and Elizabeth Stuyvesant. "To the Men and Women of the United States." The Birth Control Review 1 (1917).

"News from the States." The Birth Control Review (1939).

"News from the States." The Birth Control Review (1937).

"News from the States." The Birth Control Review (1938).

Sanger, Margaret. "Shall We Break This Law?" The Birth Control Review 1 (1917).

_. "The Aim." The Woman Rebel, March 1914.

"The Southern Regional Conference." The Birth Control Review (1938).

"What Congress Has Done to Date About Birth Control Legislation." Congressional Digest 10 (1931): 2.

"What the Birth Control Leagues Are Doing." The Birth Control Review 1 (1917).

\section{Legal Documents}

Eisenstadt, Sheriff v. Baird, 405 U.S. 438 (Supreme Court of the United States 1972).

Griswold v. Connecticut, 381 U.S. 479 (Supreme Court of the United States 1965).

United States v. Dennett, 39 F.2d 564 (Second Circuit Court of Appeals 1930).

\section{Secondary Sources}

\section{Journal Articles}

Barnes, Rosanna L. "Birth Control in Popular Twentieth-Century Periodicals." The Family Coordinator 19 (1970). 
Brenner, Barbara Laslett and Johanna. "Gender and Social Reproduction:

Historical Perspectives." Annual Review of Sociology 15 (1989).

Dawson, Deborah A., Denise J. Meny, Jeanne Clare Ridley. "Fertility Control in the United States before the Contraceptive Revolution." Family Planning Perspectives 12 (1980).

Degler, Carl N. "What Ought to Be and What Was: Women's Sexuality in the Nineteenth Century." The American Historical Review. 79 (1974).

Donaldson, Peter J. "American Catholicism and the International Family Planning Movement." Population Studies 42 (1988).

Gilmore, Glenda E. "Liberty and Sexuality: The Right to Privacy and the Making of Roe V. Wade." The Journal of Southern History. 62 (1996): 1.

Junod, Suzanne White. "The Pill at 40." The FDA Consumer 34 (2000).

Kennedy, David M. "Woman's Body, Woman's Right: A Social History of Birth Control in America." The Journal of American History. 64 (1977): 1.

Lemons, J. Stanley. "Woman's Body, Woman's Right: A Social History of Birth Control in America." The American Historical Review. 82 (1977): 1.

Lindemann, Constance. "Woman's Body, Woman's Right." The American Journal of Sociology. 83 (1978): 2.

Mohr, James C. "Sexuality, Reproduction, Contraception, and Abortion: A Review of Recent Literature." Journal of Women's History. 8 (1996): 12.

Rosenberg, Gerald N. "Liberty and Sexuality: The Right to Privacy and the Making of 'Roe V. Wade'." Contemporary Sociology. 23 (1994): 2.

Rouda, F. H. "Enovid to Norinyl." Barrons' National Business and Financial Weekly, July 301962.

Shrage, Laurie. "From Reproductive Rights to Reproductive Barbie: Post-Porn Modernism and Abortion." Feminist Studies. 28 (2002): 33.

Tushnet, Mark. "Liberty and Sexuality: The Right to Privacy and the Making of Roe V. Wade." Journal of Interdisciplinary History. 26 (1995): 1.

\section{Pamphlets}

Cosby, Elizabeth. "Family Planning in Kentucky: A History." 1973. 


\section{Published Materials}

Beisel, Nicola Kay. Imperiled Innocents: Anthony Comstock and Family Reproduction in Victorian America. Princeton: Princeton University Press, 1997.

Bonavoglia, Angela. The Choices We Made: 25 Women and Men Speak out About Abortion. New York: Random House, 1991.

Brodie, Janet Farrell. Contraception and Abortion in Nineteenth-Century America. Ithaca: Cornell University Press, 1994.

Brown, Dorothy M. Setting a Course: American Women in the 1920s. Boston: Twayne Publishers, 1987.

Butler, J. Douglas. Abortion, Society, and the Law. New York: Facts on File Publications, 1986.

Cannold, Leslie. The Abortion Myth: Feminism, Morality, and the Hard Choices Women Make. Hanover: Wesleyan University Press, 1998.

Chen, Constance M. "The Sex Side of Life": Mary Ware Dennett's Pioneering Battle for Birth Control and Sex Education. New York: The New Press, 1996.

Critchlow, Donald T, ed. The Politics of Abortion and Birth Control in Historical Perspective. University Park: The Pennsylvania State University Press, 1995.

Davis, Nanette J. From Crime to Choice: The Transformation of Abortion in America. Westport: Greenwood Press, 1985.

de Grazia, Edward. Girls Lean Back Everywhere: The Law of Obscenity and the Assault on Genius. New York: Random House, 1992.

D'Emilio, John and Estelle B. Freedman. Intimate Matters: A History of Sexuality in America. New York: Harper and Row Publishers, 1988.

Dollen, Charles. Abortion in Context: A Select Bibliography. Metuchen, N.J.: Scarecrow Press, 1970.

Douglas, Emily Taft. Margaret Sanger: Pioneer of the Future. Chicago: Holt, Rinehart, and Winston, 1970.

Evans, Sara M. Born for Liberty: A History of Women in America. New York: The Free Press, 1989.

Fields, Armond. Katharine Dexter McCormick: Pioneer for Women's Rights. Westport: Praeger, 2003. 
Garrow, David J. Liberty and Sexuality: The Right to Privacy and the Making of Roe V. Wade. New York: MacMillan Publishing Company, 1994.

Giele, Janet Zollinger. Two Paths to Women's Equality: Temperance, Suffrage, and the Origins of Modern Feminism. New York: Twayne Publishers, 1995.

Gordon, Linda. The Moral Property of Women: A History of Birth Control Politics in America. Chicago: University of Illinois Press, 2002.

-Woman's Body, Woman's Right: Birth Control in America. New York: Penguin Books, 1974.

Grossberg, Michael. Governing the Hearth: Law and the Family in Nineteenth-Century America. Chapel Hill: University of North Carolina Press, 1985.

Hoffer, Peter Charles. Murdering Mothers: Infanticide in England and New England, 1558-1803. New York: New York University Press, 1981.

Institute, Alan Guttmacher. Family Planning, Contraception, Voluntary Sterilization, and Abortion: An Analysis of Laws and Policies in the United States, Each State and Jurisdiction, October 1, 1976. Rockville: U.S. Dept of Health, Education, and Welfare, 1976.

Johnston, Carolyn. Sexual Power: Feminism and the Family in America. Tuscaloosa: The University of Alabama Press, 1992.

Kennedy, David M. Birth Control in America: The Career of Margaret Sanger. New Haven: Yale University Press, 1970.

McCann, Carole R. Birth Control Politics in the United States, 1916-1945. Ithaca: Cornell University Press, 1994.

Meier, Deborah McFarlane and Kenneth. The Politics of Fertility Control. New York: Chatham House Publishers, 2001.

Mersky, Roy M. A Documentary History of the Legal Aspects of Abortion in the United States. Griswold V. Connecticut. Littleton, CO: Fred B. Rothman Publications, 2001.

Mohr, James C. Abortion in America: The Origins and Evolution of National Policy. New York: Oxford University Press, 1978.

Moore, Gloria and Ronald Moore. Margaret Sanger and the Birth Control Movement: A Bibliography, 1911-1984. Metuchen, N.J.: The Scarecrow Press, Inc., 1986. 
Nossiff, Rosemary. Before Roe: Abortion Policy in the States. Philadelphia: Temple University Press, 2001.

Olasky, Marvin, N. Abortion Rites: A History of Abortion in America. Wheaton, IL.: Crossways Books, 1992.

- The Press and Abortion, 1838-1988. Hillsdale, N.J.: L. Erlbaum Associates, 1988.

Reagan, Leslie J. When Abortion Was a Crime: Women, Medicine, and Law in the United States, 1867-1973. Berkeley: University of California Press, 1997.

Reed, James. From Private Vice to Public Virtue: The Birth Control Movement and American Society since 1830. New York: Basic Books, Inc., Publishers, 1978.

Riddle, John M. Eve's Herbs: A History of Contraception and Abortion in the West. Cambridge: Harvard University Press, 1997.

Sachdev, Paul. Perspectives on Abortion. Metuchen, N.J.: The Scarecrow Press, Inc., 1985.

Schoen, Johanna. Choice and Coercion: Birth Control, Sterilization, and Abortion in Public Health and Welfare. Chapel Hill: The University of North Carolina Press, 2005.

Smith, David T. Abortion and the Law; Essays by B. James George, Jr., Western Reserve Law Review. Cleveland: Press of Western Reserve University, 1967.

Solinger, Rickie. Pregnancy and Power: A Short History of Reproductive Politics in America. New York: New York University Press, 2005.

Stetson, Dorothy M. Abortion Politics, Women's Movements, and the Democratic State: A Comparative Study of State Feminism. New York: Oxford University Press, 2001.

Tribe, Laurence. Abortion: The Clash of Absolutes. New York: W.W. Norton \& Company, 1992.

Ulrich, Laurel. A Midwive's Tale: The Life of Martha Ballard, Based on Her Diary, 1785-1812. New York: Vintage Books, 1991.

Westoff, Leslie Aldridge and Charles F. Westoff. From Now to Zero: Fertility, Contraception and Abortion in America. Boston: Little, Brown and Company, 1968.

Wexler, Alice. Emma Goldman: An Intimate Life. New York: Pantheon Books, 1984. 
Wheeler, Leigh Ann. Against Obscenity: Reform and the Politics of Womanhood in America, 1873-1935. Baltimore: The Johns Hopkins University Press, 2004.

\section{Unpublished Materials}

Block, Mary R. "An Accusation Easily to Be Made: A History of Rape Law in Nineteenth-Century State Appellate Courts, 1800-1870." University of Louisville, 1992.

Hurt, Lucille Baker. "The Clients of the Planned Parenthood Clinic of Louisville, Kentucky,." Masters Thesis, University of Louisville, 1962.

Myers, Judith Gay. "A Socio-Historical Analysis of the Kentucky Birth Control Movement, 1933-1943." University of Kentucky, 2005. 


\section{CURRICULUM VITAE}

NAME: $\quad$ Elizabeth Leigh Caskey

ADDRESS: $\quad 1514 \mathrm{~S}^{\text {rd }} \mathrm{St} \mathrm{Apt} \mathrm{\# 4}$

Louisville, KY 40208

DOB: $\quad$ Tampa, Florida - April 15, 1983

EDUCATION: $\quad$ B.A., History, magna cum laude

Bellarmine University, Louisville, Kentucky

2001-2005

M.A., History

University of Louisville

2005-present

AWARDS AND HONORS: Thomas Hamilton Graduate Scholarship, University of Louisville, 2005

Dean's List, Bellarmine University, Spring 2002-Fall 2004

Monsignor Horrigan Undergraduate Scholarship, Bellarmine University, 2001-2005

WORK EXPERIENCE: University of Louisville

Student Research Assistant, Fall 2005- present

Bellarmine University

Peer Tutor, Fall 2004-Spring 2005

History 116: World Civilizations

German 101 and 102

Bellarmine University

Help Desk Work Study Student, Fall 2001-

Spring 2005 